
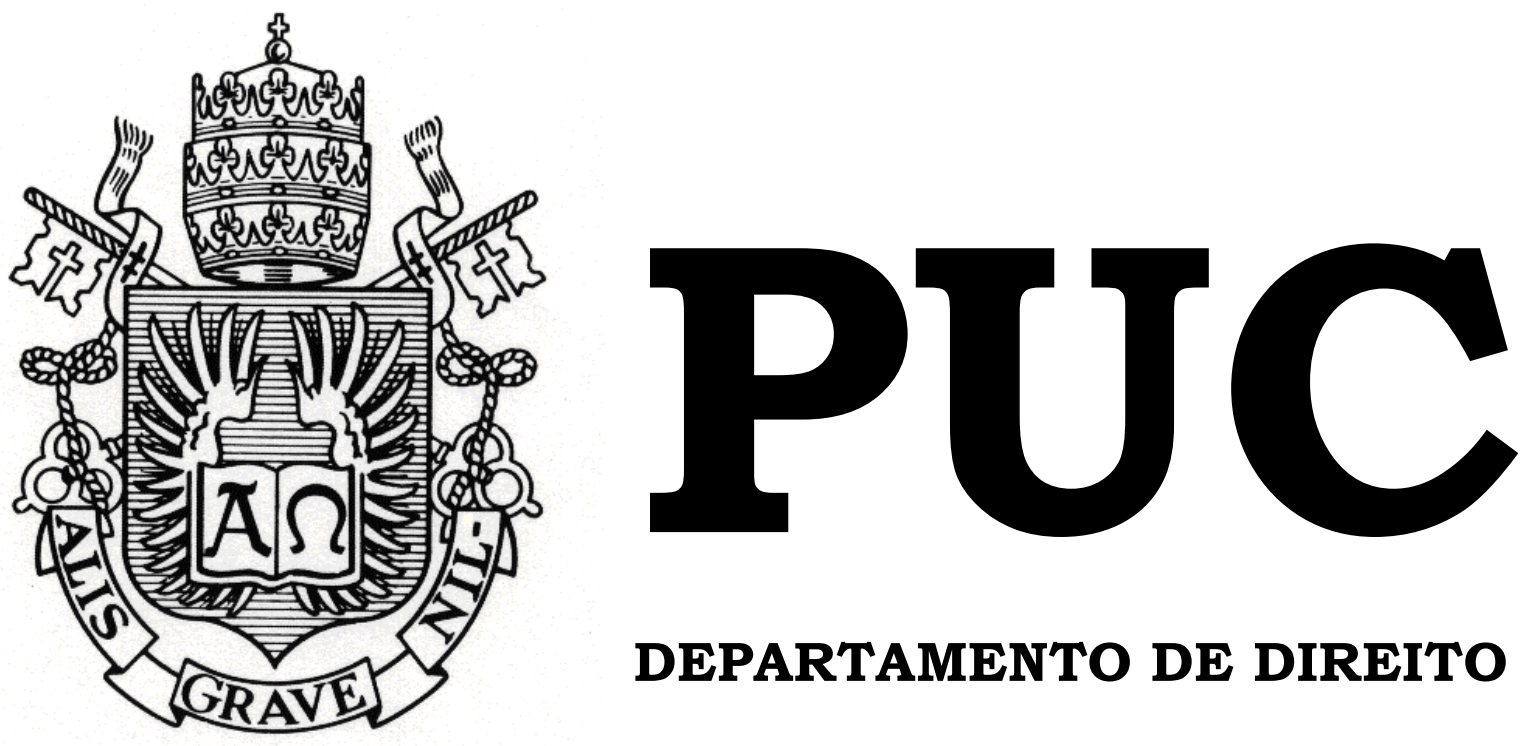

DEPARTAMENTO DE DIREITO

ARBITRAGEM NO CONTRATO DE CONCESSÃO PARA EXPLORAÇÃO E PRODUÇÃO DE PETRÓLEO E GÁS NATURAL

por

GABRIELA CORRÊA DA COSTA BEZERRA

ORIENTADOR: MANOEL MESSIAS PEIXINHO

2012.2

PONTIFÍCIA UNIVERSIDADE CATÓLICA DO RIO DE JANEIRO

RUA MARQUÊS DE SÃO VICENTE, 225 - CEP 22453-900

RIO DE JANEIRO - BRASIL 


\title{
ARBITRAGEM NO CONTRATO DE CONCESSÃO PARA EXPLORAÇÃO E PRODUÇÃO DE PETRÓLEO E GÁS NATURAL
}

\author{
por
}

\section{GABRIELA CORRÊA DA COSTA BEZERRA}

\author{
Monografia apresentada ao \\ Departamento de Direito da \\ Pontificia Universidade Católica \\ do Rio de Janeiro (PUC-Rio) para \\ a obtenção do Título de Bacharel \\ em Direito.
}

Orientador: Manoel Messias

Peixinho

\section{2}


Ao meu pai, por ter tornado tudo possível. 


\section{AGRADECIMENTOS}

Gostaria de agradecer a todos os amigos e familiares que de direta ou indiretamente contribuíram para a realização deste trabalho, especialmente:

À minha mãe, Alda, meu exemplo de dedicação e perseverança.

À minha irmã, Fernanda, não só pela ajuda essencial à elaboração deste trabalho, mas pelo companheirismo da vida inteira.

À Raquel, que tanto contribuiu para a minha formação, pelas lições preciosas.

Ao meu namorado, Paulo, pela cumplicidade, paciência e suporte desses e de todos os dias.

Ao Edu, por todo o apoio nesse início da minha carreira jurídica.

Ao Antonio, Felipe e Maria Isabel, por tornarem os meus dias mais alegres, e o trabalho, mais leve.

À Mariana, minha dupla, por dividir comigo as alegrias e aflições do dia-adia.

Ao Manoel Peixinho, meu orientador, pela confiança depositada. 


\section{RESUMO}

A proposta deste trabalho é a análise da possibilidade, dos limites e das vantagens da adoção da arbitragem como meio alternativo de solução de controvérsias oriundas do Contrato de Concessão para Exploração, Desenvolvimento e Exploração de Petróleo e Gás Natural. Para tanto, primeiramente, analisaremos o instituto da arbitragem, através de um breve histórico, da análise dos aspectos mais relevantes da Lei no . 9.307/96 e da sua natureza jurídica. Em seguida, estudaremos o objeto, natureza jurídica e cláusulas essenciais do contrato de concessão da atividade petrolífera. Por fim, abordaremos o tema em si, inicialmente sob a perspectiva da submissão da Administração Pública à arbitragem, analisando a questão a partir dos princípios constitucionais que regem a atuação do Estado, além do leading case julgado pelo STF, conhecido como Caso Lage. Além disso, analisaremos a cláusula compromissória inserida no âmbito do contrato de concessão celebrado entre o concessionário e a ANP e as vantagens decorrentes da adoção da arbitragem para a solução das controvérsias oriundas desse contrato, especialmente diante das características próprias da indústria petrolífera.

Palavras-chave: Arbitragem. Contrato de Concessão para Exploração, Desenvolvimento e Produção de Petróleo e Gás Natural. Interesse Público Primário e Secundário. Indisponibilidade do Interesse Público. Princípio da Legalidade. Princípio da Publicidade. 


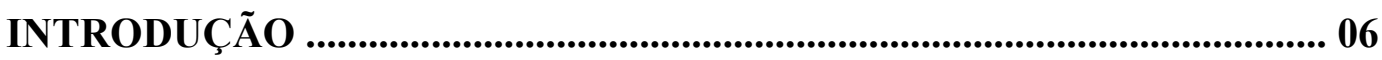

CAPÍTULO 1 - ARBITRAGEM ............................................................... 09

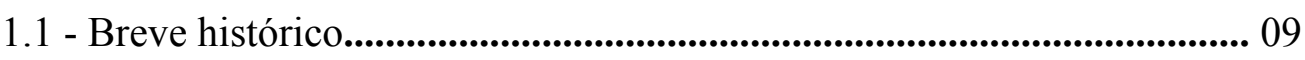

1.2. - A Lei 9.307/1996, de 23 de setembro de 1996 ...................................... 11

1.2.1 - Arbitrabilidade objetiva e arbitrabilidade subjetiva...................... 12

1.2.2 - Cláusula compromissória e compromisso arbitral........................ 16

1.3 - Natureza Jurídica......................................................................................... 18

CAPÍTULO 2 - O CONTRATO DE CONCESSÃO PARA EXPLORAÇÃO, DESENVOLVIMENTO E PRODUÇÃO DE PETRÓLEO E GÁS NATURAL................................................................................................... 21

2.1. Objeto......................................................................................... 23

2.2. Natureza Jurídica...................................................................................... 26

2.3. Cláusulas Essenciais.................................................................................. 31

CAPÍTULO 3 - ARBITRAGEM NO CONTRATO DE CONCESSÃO DE EXPLORAÇÃO E PRODUÇÃo DE PETRÓLEO E GÁS NATURAL... 35

3.1 A Arbitragem na Administração Pública em Geral.................................... 35

3.1.1 Arbitrabilidade subjetiva - o Caso Espólio de Henrique Lage vs. União Federal........................................................................................... 36

3.1.2 Interesse Público Primário e Interesse Público Secundário......... 38

3.1.3 Principio da indisponibilidade do interesse público...................... 44

3.1.4 Princípio da Publicidade.................................................................... 49

3.1.5 Princípio da Legalidade.................................................................. 51

3.2 A Cláusula Compromissória no Contrato de Concessão para Exploração, Desenvolvimento e Produção de Petróleo e Gás Natural......................................................................................................... 53

3.3 Vantagens da adoção da arbitragem como meio extrajudicial de solução de conflitos...................................................................................................... 56

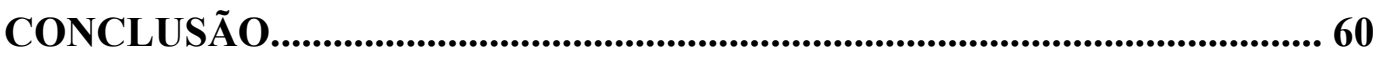

REFERÊNCIAS BILIOGRÁFICAS...........................................................6 64 


\section{INTRODUÇÃO}

O presente trabalho se propõe a analisar a adoção da arbitragem nos contratos de concessão da atividade petrolífera. Sendo os contratos de concessão celebrados entre o concessionário vencedor da licitação e o Estado, enquanto Poder Concedente, a adoção da arbitragem para dirimir as controvérsias oriundas de tal contrato envolve todas as considerações pertinentes à submissão da Administração Pública em geral a um meio extrajudicial de solução de conflitos.

Nesse sentido, o tema é amplamente debatido na doutrina, especialmente em razão de os atos do administrador serem regidos pelas normas de Direito Público, o que, em uma primeira análise, demonstra-se incompatível com a submissão às normas de Direito Privado que regem a arbitragem ${ }^{1}$. Além disso, a indisponibilidade do interesse público também se demonstra um óbice, a priori, a que o Estado se submeta a um meio alternativo de composição de litígios.

Por outro lado, os contratos de concessão para exploração e produção de petróleo são dotados de natureza jurídica peculiar, não podendo ser igualados aos contratos de concessão de serviços públicos. Além disso, a adoção de cláusulas arbitrais nos contratos relacionados à atividade petrolífera é prática corrente na indústria ${ }^{2}$, mostrando-se compatível com as características da mesma.

\footnotetext{
${ }^{1}$ LEMES, Selma. Arbitragem na Administração Pública - Fundamentos Jurídicos e Eficiência Econômica. São Paulo: Quartier Latin, 2007. p. 19.

2 MUNIZ, Joaquim de Paiva. Os Limites da Arbitragem nos Contratos de Concessão de Exploração e Produção de Petróleo e Gás Natural. Revista de Arbitragem e Mediação, ano 1, no. 2, maio - agosto de 2004. p. 90.
} 
Portanto, o presente trabalho visa apresentar a possibilidade, os limites e as vantagens da utilização da arbitragem para a solução das controvérsias oriundas dos contratos de concessão para exploração e produção de petróleo.

Para tanto, iniciaremos com a análise do instituto da arbitragem. Tal análise incluirá um breve histórico a fim de identificar a origem do instituto, bem como a sua previsão no ordenamento jurídico brasileiro ao longo do tempo. Além disso, também será objeto de estudo a Lei no . 9.307, de 23 de setembro de 1996 ("Lei de Arbitragem”) que atualmente é o diploma legal que rege a arbitragem e cujo advento assegurou a ampla utilização do instituto no país. Com relação à Lei de Arbitragem, serão analisados os pontos mais relevantes ao tema, notoriamente a arbitrabilidade objetiva e subjetiva e a convenção de arbitragem.

Já no segundo capítulo trataremos do Contrato de Concessão para Exploração, Desenvolvimento e Produção de Petróleo e Gás e Natural, abordando a sua natureza jurídica, objeto e cláusulas essenciais. O foco desse capítulo será a natureza sui generis desse contrato, na medida em que, como se verá, não se trata de concessão de serviço público, mas de atividade econômica, atraindo a natureza jurídica de Direito Privado, o que, por outro lado, não tem o condão de afastar as normas publicistas aplicáveis a esse contrato.

Mais adiante entraremos no tema central do presente trabalho: a arbitragem nos contratos de concessão das atividades de exploração e produção de petróleo. Exploraremos o tema, primeiramente, a partir da possibilidade de submissão da Administração Pública em geral à arbitragem. Nesse ponto, identificaremos, em primeiro lugar, a arbitrabilidade subjetiva dos litígios envolvendo o Estado, a partir do precedente histórico do Supremo Tribunal Federal conhecido como "Caso Lage". Além disso, analisaremos a questão sob a ótica de princípios que 
regem a Administração Pública e que, em um primeiro olhar, poderiam constituir óbice a que essa se submeta à Arbitragem. São eles: o princípio da indisponibilidade do interesse público, o princípio da publicidade e o princípio da legalidade.

Ademais, o presente trabalho fará ainda uma análise da cláusula compromissória inserida nos contratos de concessão da atividade petrolífera desde a Rodada Zero, promovida pela ANP.

Por fim, serão levantadas as vantagens oriundas da adoção da arbitragem para a solução de conflitos, em geral e especificamente com relação aos contratos de concessão para exploração e produção de petróleo, tendo como base as características da indústria. Além disso, analisaremos os benefícios oriundos da adoção da via arbitral em face dos princípios constitucionais. 


\section{CAPÍTULO 1 - ARBITRAGEM}

Esse capítulo se prestará à análise do instituto da arbitragem. Estudaremos as suas origens e o caminho percorrido na legislação constitucional e infraconstitucional brasileira até o advento da Lei $n^{\circ}$. 9.307, de 23 de setembro de 1996. Além disso, analisaremos os ditames da Lei de Arbitragem que mais interessam à questão principal do presente trabalho.

\section{1 - Breve histórico}

A origem mais primitiva do instituto da arbitragem remonta ao Direito Romano. Indícios históricos demonstram que antes mesmo da formação do poder estatal, os particulares já se organizavam para dirimir as controvérsias oriundas das suas relações interpessoais, sendo estas solucionadas pelos próprios litigantes ou pelos grupos a que pertenciam ${ }^{3}$. Além disso, segundo leciona J.E. CARREIRA ALVIM, a transposição dessa justiça privada para uma justiça estatal teria sido "produto de uma lenta e segura evolução". ${ }^{4}$

Além disso, quase todos os estatutos da Idade Média previam expressamente o instituto do compromisso arbitral, incluindo-se a Lei das Doze Tábuas, o direito romano e o direito canônico. Insta ressaltar que em Roma vigoraram dois tipos de procedimentos arbitrais: o facultativo, fruto do acordo entre as partes e o obrigatório, pelo qual o Estado obrigava as partes a escolherem um árbitro para pôr fim à controvérsia, bem como para garantir a execução da sentença 5 .

\footnotetext{
${ }^{3}$ CARREIRA ALVIM, J.E. Comentários à Lei de Arbitragem (Lei $n^{\circ}$ 9.307, de 23/09/1996). $2^{\mathrm{a}}$ ed. Atualizada. Rio de Janeiro: Editora Lumen Juris, 2004. p. 1.

${ }^{4}$ Ibid.

${ }^{5}$ CARREIRA ALVIM, J.E. Op. cit., p. 2-3.
} 
Tendo o direito canônico e romano sido ministrado nas escolas e no foro Português, já no século XIII "era admitido o uso de recorrer-se aos amigáveis compositores ou compromissário" em território lusitano. Essa legislação passou também a viger no Brasil por força da carta de lei de 20 de outubro de $1823 .^{6}$

Contudo, com o advento da Constituição de 1824, a própria Constituição brasileira passou a prever expressamente a possibilidade de solução de controvérsias por meio da arbitragem. Nesse sentido, o art. 160 da Carta previa que:

“Art. 160. Nas causas cíveis e nas causa penais civilmente intentadas, poderão as partes nomear juízes árbitros. Suas sentenças são executadas sem recurso, se assim o convencionarem as partes."

A partir da previsão constitucional foram editados diversos normativos visando à regulamentação do instituto da arbitragem no Brasil.

Contudo, com ao advento da Constituição Republicana de 1891 a arbitragem perdeu previsão Constitucional, sendo mantida, entretanto, a sua existência no ordenamento jurídico brasileiro por meio da legislação infraconstitucional.

Além disso, insta ressaltar que o Código Civil de 1916, em seu art. 136, n. VII previa o arbitramento como meio de prova de atos jurídicos, a título de fixar o valor a retribuir na locação de serviços (art. 1.218), na liquidação de obrigações (art. 1.536, $\S 1^{\circ}$ ) ou no ressarcimento de ato ilícito $(\text { art. } 1.533)^{7}$.

Mais adiante, em 1939, o Código de Processo Civil, disciplinou detalhadamente o juízo arbitral, com ressalva da necessidade de

\footnotetext{
${ }^{6}$ Ibid.

${ }^{7}$ TÁCITO, Caio. O juizo Arbitral em Direito Administrativo. In: Reflexões sobre Arbitragem: in memoriam do Desembargador Cláudio Vianna de Lima/coord. Petro A. Batista Martins, José Maria Rossani Garcez - São Paulo: LTr, 2002. p. 23.
} 
homologação judicial, não obstante a inexistência de referência ao tema na Constituição Varguista em vigor ${ }^{8}$.

O silêncio constitucional a respeito do instituto da arbitragem persistiu durante as Constituições seguintes, datadas de 1946, 1967 e 1969. Ainda assim, o Código de Processo Civil instituído pela Lei no . 5.869, de 11 de janeiro de 1973 dedicou um capítulo a tutelar o juízo arbitral ${ }^{9}$.

Com o advento da Constituição de 1988 a arbitragem ganhou novamente status constitucional, estando prevista no art. $114, \S \S 1^{\circ}$ e $2^{\circ 10}$ para litígios trabalhistas.

Contudo, foi com a promulgação da Lei $\mathrm{n}^{\circ}$. 9.307, de 23 de setembro de 1996 ("Lei de Arbitragem") que a arbitragem passou a ser amplamente tutelada no direito brasileiro. Comemorada pela sociedade e pela doutrina pátria, a Lei “imprimiu modernidade ao instituto da arbitragem" 11, introduzindo uma alternativa concreta à morosidade do Poder Judiciário na solução de litígios.

\section{2 - A Lei n. 9.307, de 23 de setembro de 1996}

Para PEDRO A. BATISTA MARTINS o advento da Lei de Arbitragem reflete a liberdade do cidadão frente ao Estado e às suas limitações. Nesse sentido, o autor leciona:

"É o início de nova cultura de uma sociedade participativa, ciosa de seus direitos, mas, sobretudo, consciente de seus deveres. É a confirmação de que o Estado contemporâneo, negligente, é devedor de mais atenção aos seus pressupostos básicos e, para cumpri-los, deve aceitar suas limitações, não como fraquezas e, sim, como oportunidade de cooptar a parceria da sociedade, atribuindo-lhe

\footnotetext{
${ }^{8}$ TÁCITO, Caio. Op. cit., p. 23.

${ }^{9}$ CARREIRA ALVIM, J.E. Op. cit., p. 5.

10 “Art. 114. Compete à Justiça do Trabalho processar e julgar: (...)§ $1^{\circ}$ - Frustrada a negociação coletiva, as partes poderão eleger árbitros. $\S 2^{\circ}$ Recusando-se qualquer das partes à negociação coletiva ou à arbitragem, é facultado às mesmas, de comum acordo, ajuizar dissídio coletivo de natureza econômica, podendo a Justiça do Trabalho decidir o conflito, respeitadas as disposições mínimas legais de proteção ao trabalho, bem como as convencionadas anteriormente."

${ }^{11}$ TÁCITO, Caio. Op. cit., p. 23.
} 
maiores responsabilidades. O Estado não é um fim em si mesmo. Afinal, todo o poder emana do povo, e deve ser exercido para o povo e pelo o povo ${ }^{12}$."

Assim é que, a Lei de Arbitragem, ao regulamentar o instituto, viabilizou a sua ampla utilização no país. Entretanto, como não poderia deixar de ser, referida Lei impôs limites e requisitos à composição por meio de arbitragem. Isso porque, a Constituição Federal assegura o direito ao acesso à justiça, ao positivar o princípio da inafastabilidade da jurisdição, previsto no art. $5^{\circ}, \mathrm{XXXV}$ da Constituição segundo o qual "a lei não excluirá da apreciação do Poder Judiciário lesão ou ameaça a direito". Desse modo, foi necessário que o legislador balizasse a utilização da arbitragem como meio de solução extrajudicial de controvérsias a fim de não ir de encontro com o princípio constitucional da inafastabilidade do poder jurisdicional. Analisaremos a seguir quais foram essas balizas impostas pela Lei, além dos principais aspectos do instituto da arbitragem.

\subsection{1 - Arbitrabilidade objetiva e arbitrabilidade subjetiva}

Já em seu artigo $1^{\circ}$ a Lei de Arbitragem estabelece uns dos principais limites à utilização da arbitragem para solução de controvérsias. Referido artigo prescreve que:

"Art. $1^{\circ}$ As pessoas capazes de contratar poderão valer-se da arbitragem para dirimir litígios relativos a direitos patrimoniais disponíveis."

Do artigo acima se extrai que para que um litígio possa ser submetido à arbitragem, deve ser composto por pessoas capazes e seu objeto deve se relacionar a direitos patrimoniais disponíveis. Assim, CARLOS ALBERTO CARMONA resume o conceito de arbitragem da seguinte maneira:

"A arbitragem - meio alternativo de resolução de controvérsias através da intervenção de uma ou mais pessoas que recebem seus poderes de uma convenção privada, decidindo com base nela, sem intervenção estatal, sendo a decisão destinada a assumir a mesma eficácia da sentença judicial - é colocada à

\footnotetext{
${ }^{12}$ MARTINS, Pedro A. Batista. Apontamentos sobre a Lei de Arbitragem. $1^{\mathrm{a}}$ ed. Rio de Janeiro: Editora Forense, 2008.
} 
disposição de quem quer que seja, para solução de conflitos relativos a direitos patrimoniais acerca dos quais os litigantes possam dispor". ${ }^{13}$

Os artigos $3^{\circ}$ e $4^{\circ}$ do Código Civil Brasileiro cuidam da definição da incapacidade civil. Segundo tais artigos são absolutamente incapazes os (i) menores de dezesseis anos; (ii) os que, por enfermidade ou deficiência mental, não tiverem o necessário discernimento para a prática desses atos; e (iii) os que, mesmo por causa transitória, não puderem exprimir sua vontade. Já os relativamente incapazes são (i) os maiores de dezesseis e menores de dezoito anos; (ii) os ébrios habituais, os viciados em tóxicos, e os que, por deficiência mental, tenham o discernimento reduzido; (iii) os excepcionais, sem desenvolvimento mental completo; (iv) os pródigos.

Além disso, o Código Civil estabelece, ainda, serem nulos os negócios jurídicos celebrados por absolutamente incapazes e anuláveis os celebrados por relativamente incapazes, conforme artigos 166, I e 171, I.

Portanto, considerando que, como se verá mais adiante, para que uma controvérsia seja submetida ao juízo arbitral é necessário que as partes estabeleçam uma convenção arbitral, ou seja, um pacto, oriundo da livre manifestação da vontade, essa somente pode ser legitimamente assumida por pessoas capazes para os atos da vida civil

Insta ressaltar que o texto da lei se limita a mencionar as "pessoas capazes de contratar”, não fazendo, portanto, distinção entre pessoas físicas e jurídicas. Assim, é pacífico na doutrina que podem se submeter à arbitragem tanto pessoas físicas quanto jurídicas, desde que dotadas de capacidade contratual, conforme defende CAIO TÁCITO:

"[A Lei de Arbitragem] Limita-se a definir o seu âmbito como meio apto de opção em relações patrimoniais entre pessoas capazes de contratar. A rigor, não estarão, portanto, isentas de seu alcance as pessoas jurídicas que possam validamente assumir obrigações de natureza bilateral". ${ }^{14}$

\footnotetext{
${ }^{13}$ CARMONA, Carlos Aberto. Arbitragem e processo - um comentário à Lei no ${ }^{\circ}$ 9.307/96. $2^{\mathrm{a}}$ ed. São Paulo: Atlas, 2009. p. 31.

${ }^{14}$ TÁCITO, Caio. Op. cit., p. 24 e 25.
} 
Igualmente não se encontra na Lei distinção entre pessoas jurídicas de direito público e de direito privado no tange à possibilidade de se submeterem ao juízo arbitral, o que nos leva ao entendimento de que inexiste vedação a que as pessoas jurídicas de direito público participem de arbitragem. Essa matéria já foi decidida pelo Supremo Tribunal Federal, no famoso caso envolvendo o espólio de Henrique Lage e a União Federal, tendo restado "claro que não haveria nenhuma vedação per se a que pessoas jurídicas de direito público participassem de arbitragem" 15 .

Desse modo, o primeiro requisito a determinar se uma controvérsia pode ser dirimida por meio de arbitragem é um requisito subjetivo, ou seja, que diz respeito aos sujeitos, às partes da arbitragem. Nesse sentido, somente podem se submeter à arbitragem as pessoas dotadas de capacidade para exercer a sua liberdade contratual.

A existência da capacidade de contratar como pressuposto para a adoção da arbitragem é intitulada pela doutrina como arbitrabilidade subjetiva, ou arbitrabilidade ratione personae. Assim, considera-se como dotada de arbitrabilidade subjetiva a controvérsia envolvendo partes capazes, sejam elas físicas ou jurídicas, de direito público ou privado. A esse respeito, JOAQUIM DE PAIVA MUNIZ ensina que:

"A arbitrabilidade subjetiva refere-se à capacidade da parte de se submeter ao procedimento arbitral e, como acima exposto, não há proibição, em princípio, a que a pessoa jurídica de direito público participe da arbitragem" 16 .

Além da arbitrabilidade subjetiva, o artigo $1^{\mathrm{o}}$ da Lei de Arbitragem traz mais um requisito para a utilização do instituto, sendo esse de caráter objetivo. Nesse sentido, PONTES DE MIRANDA ensina que:

"Não se trata, porém, de única exigência, que seria a de capacidade negocial. É preciso que, no que respeito ao objeto, possa dispor, transigir. Não basta, portanto, ser apenas capaz de contratar. A capacidade é elemento subjetivo.

(...)

${ }^{15}$ MUNIZ, Joaquim de Paiva, Os Limites da Arbitragem nos Contratos de Concessão de Exploração e Produção de Petróleo e Gás Natural. Revista de Arbitragem e Mediação, ano 1, no. 2, maio - agosto de 2004, p. 91.

${ }^{16} \mathrm{Ibid}$. 
Se a pessoa, a respeito do direito patrimonial, ou dos direitos patrimoniais, de que se cogita para o juízo arbitral, pode transigir, é-lhe permitido louvar-se em árbitro, ou em árbitros". ${ }^{17}$ (grifo no original)

Assim, o artigo $1^{\circ}$ da Lei de Arbitragem aduz a que apenas litígios que envolvam direitos patrimoniais disponíveis podem ser objeto de arbitragem. Essa é a denominada arbitrabilidade objetiva, ou seja, é a verificação da possibilidade de se recorrer ao juízo arbitral para solucionar determinada controvérsia a partir do objeto do litígio.

A definição de direitos patrimoniais disponíveis vem sendo amplamente discutida na doutrina. Primeiramente, insta ressaltar que os direitos patrimoniais disponíveis a que se refere a lei são os pertencentes à categoria de direito subjetivo" ${ }^{18}$, definido por Jellinek como "o poder atribuído à vontade do sujeito e garantido pelo ordenamento jurídico , para satisfação de próprios interesses". ${ }^{19}$

Frequentemente se entende como direito patrimonial aquele com conteúdo econômico, avaliáveis pecuniariamente ${ }^{20}$. Nesse sentido, são direitos patrimoniais os direitos reais, direitos autorais e pessoais.

Em oposição aos direitos patrimoniais há os direitos extrapatrimoniais, entendidos como aqueles inerentes à condição de pessoa humana, englobando os direitos da personalidade e os da família. Compreendem, portanto, o direito à vida, à liberdade, à integridade física, ao nome, à honra, à intimidade. ${ }^{21}$ Tais direitos, portanto, não podem ser tutelados por meio de arbitragem, tampouco qualquer meio alternativo de composição de litígios.

\footnotetext{
${ }^{17}$ PONTES DE MIRANDA, Comentários, tomo XV, nos. 09 - 10. p. 265-266. Apud FIGUEIRA Junior, Joel Dias; Arbitragem, Jurisdição e Execução, São Paulo: Ed. Revista dos Tribunais, 1999. ${ }^{18}$ MATTOS Neto, Antonio José. Direitos Patrimoniais disponiveis e indisponíveis à luz da Lei de Arbitragem, Revista de Processo. São Paulo, v. 27, n. 106, Abril - Jun 2002. p. 222.

${ }^{19}$ GOMES, Orlando. Introdução do direito civil. $10^{\mathrm{a}}$ ed. Rio de Janeiro: Forense, 1988. p. 112.

${ }^{20}$ DA SILVA PEREIRA, Cario Mario. Instituiçõs de Direito Civil. 23 $3^{\mathrm{a}}$ ed. Rio de Janeiro: Forense, 2010. p. 67.

${ }^{21}$ MATTOS Neto, Antonio José. Op. cit., p. 223.
} 
Já o direito disponível é aquele entendido como “alienável, transmissível, renunciável, transacionável". ${ }^{22}$ Nesse sentido, o titular desse direito pode dele dispor livremente, alienando-o, transmitindo-o tanto inter vivos quanto causa mortis, além de renunciá-lo e transigi-lo.

Entretanto, é interessante notar que nem tudo o que representa utilidade econômica é disponível como, por exemplo, o bem imóvel clausulado com a inalienabilidade. ${ }^{23}$ Desse modo, via de regra os direitos patrimoniais são disponíveis, sendo, portanto, a indisponibilidade de tais direitos a exceção. ${ }^{24}$ Sendo os direitos patrimoniais indisponíveis a exceção, devem estes ser interpretados restritivamente. ${ }^{25}$

Assim, os direitos patrimoniais disponíveis a que alude a Lei de Arbitragem são aqueles que reúnem tanto as características dos direitos patrimoniais, quanto as características dos direitos disponíveis, Para ALEXANDRE SANTOS DE ARAGÃO os direitos patrimoniais disponíveis podem ser compreendidos como "aqueles que, por serem suscetíveis de valoração econômica, integram o patrimônio e podem ser livremente negociados por seus titulares com terceiros." 26

Assim, é necessário que as partes possam validamente e legalmente dispor do direito cuja tutela pretendem obter por meio do procedimento arbitral. Além disso, os direitos devem ser passíveis de valoração econômica, guardando relação com o patrimônio das partes.

\subsection{2 - Cláusula compromissória e compromisso arbitral}

Conforme previsto no art. $3^{0}$ da Lei de Arbitragem, as partes podem submeter a solução de seus litígios ao juízo arbitral mediante convenção de

\footnotetext{
${ }^{22}$ MUNIZ, Joaquim de Paiva. Op. cit., p. 91.

${ }^{23}$ MATTOS Neto, Antonio José. Op. cit., p. 226.

${ }^{24}$ ARAGÃO, Alexandre Santos de. Arbitragem e Regulação. Revista de Arbitragem e Mediação, Coord. Arnoldo Wald, ano 7-27, out -dez 2010, Ed. Revista dos Tribunais. p. 77.

${ }^{25}$ MARTINS, Pedro A. Batista. Arbitrabilidade objetiva. Interesse public, indisponibilidade de direitos e normas de ordem pública. no. 50, v. 10, Porto Alegre: Forum, jul-ago 2002, p. 92.

${ }^{26}$ ARAGÃO, Alexandre Santos de. Op. cit., p. 77.
} 
arbitragem. Ou seja, para uma controvérsia seja submetida à arbitragem, além da arbitrabilidade objetiva e subjetiva já analisadas, é necessária a existência de acordo entre as partes, de manifestação da vontade de se valer da arbitragem, em detrimento do Poder Judiciário. Isso porque, como visto, a regra geral prevista na Constituição é a da inafastabilidade do poder jurisdicional, de modo que para que se utilizem de um meio extrajudicial de solução de controvérsias, é imprescindível que exista mútuo acordo entre as partes nesse sentido.

A convenção de arbitragem é entendida como espécie, da qual são gêneros a cláusula compromissória e o compromisso arbitral. ${ }^{27}$ Segundo a definição da lei (art. $4^{\circ}$ ) a cláusula compromissória é a "convenção através da qual as partes em um contrato comprometem-se a submeter à arbitragem os litígios que possam vir a surgir, relativamente a tal contrato". Desse modo, ao celebrarem um contrato, caso as partes optem por submeter as controvérsias dele oriundas ao juízo arbitral, inserem uma cláusula específica no contrato nesse sentido, intitulada "cláusula arbitral”.

Insta ressaltar que cláusula compromissória não pode ser tão ampla que abranja todo e qualquer litígio existente entre as partes. Nesse sentido, existe uma limitação natural que é a relação jurídica formada entre as partes por meio do contrato em que a cláusula compromissória está inserida. Com relação ao requisito formal, a legislação brasileira exige apenas que a cláusula seja celebrada por escrito, submetendo-se, portanto, aos mecanismos gerais previstos na legislação civil para a celebração de contratos. $^{28}$

Já o compromisso arbitral, definido pela Lei de Arbitragem em seu art. $9^{\circ}$ "é a convenção através da qual as partes submetem um litígio à arbitragem de uma ou mais pessoas, podendo ser judicial ou extrajudicial." Logo, no compromisso arbitral as partes decidem pela submissão de um

\footnotetext{
${ }^{27}$ LEMES, Selma. Op. cit., p. 60.

${ }^{28}$ CARMONA, Carlos Aberto. Op. cit., p. 105.
} 
litígio específico ao juízo arbitral, ao invés de pactuarem que todos os litígios oriundos de um determinado contrato serão dirimidos por meio de arbitragem. Nesse sentido CARLOS ALBERTO CARMONA ensina que “(...) se na celebração do compromisso tem-se em mira um conflito atual, já existente, definido, na cláusula aponta-se para um litígio futuro, eventual, definível". 29

\section{3 - Natureza Jurídica}

A natureza jurídica da arbitragem é tema controvertido na doutrina. Nesse sentido, podemos identificar três principais correntes que visam defini-la, sendo elas: a teoria contratual ou privatista, a teoria jurisdicional e a teoria híbrida. ${ }^{30}$

Para os defensores da primeira teoria, liderada por Chiovenda, a arbitragem tem natureza contratual na medida em que nasce de uma convenção firmada entre as partes ${ }^{31}$, sendo que os poderes dos árbitros são fruto dessa manifestação da autonomia da vontade das partes. Entretanto, esta teoria leva à necessidade de homologação judicial do laudo arbitral para que este possa ser legitimamente executado ${ }^{32}$, já que os árbitros seriam desprovidos de poder jurisdicional ${ }^{33}$. Contudo, esta teoria se demonstra inadequada ao ordenamento brasileiro atual, já que a Lei de Arbitragem confere ao laudo arbitral os efeitos próprios de sentença judicial, não havendo que se falar, portanto, em necessidade de homologação do laudo como requisito para a sua exequibilidade.

\footnotetext{
${ }^{29}$ CARMONA, Carlos Aberto. Op. cit., p. 102.

${ }^{30}$ LEMES, Selma. Op. cit., p. 60.

${ }^{31}$ Ibid. p. 60.

32 ENEI, José VirgílioLopes. A arbitragem nas sociedades anônimas. Revista de Direito Mercantil, Industrial, Econômico e Financeiro, São Paulo, n. 129, p. 136-173, jan./mar. 2003, p. 141. Industrial, Econômico e Financeiro, São Paulo, n. 129, p. 186-219, jan./mar.2003, p. 190.
} 
Portanto, diante dos regimes arbitrais mais modernos, a doutrina passou a interpretar o poder jurisdicional de forma mais abrangente, a fim de que seja englobada por tal conceito a atuação do árbitro no procedimento arbitral. $^{34}$ Nesse sentido, o fato do árbitro não ser provido de poder coercitivo não impede que seja reconhecido o seu poder jurisdicional, na medida em que a coercibilidade é apenas uma das espécies de jurisdição, não havendo necessidade que todas as espécies estejam reunidas no mesmo ente ou na mesma pessoa para que se exerça o poder jurisdicional. ${ }^{35}$

Assim a teoria jurisdicional, defendida por Ludovico Mortara e, no Brasil, por Carlos Carmona, entende que em virtude do resultado da arbitragem ser o julgamento, por um terceiro, imparcial, que visa pôr fim a uma controvérsia, esta teria natureza jurisdicional, e não meramente contratual. $^{36}$ Conforme mencionado acima, esta teoria se demonstra em consonância com os ditames da Lei de Arbitragem, especialmente no que se refere aos seus arts. 18 e 31 que preveem, respectivamente, que o árbitro é juiz de fato e de direito, não ficando a sentença por ele proferida sujeita a recurso ou homologação e que a sentença arbitral produz entre as partes os mesmo efeitos da sentença judicial.

Por fim, a teoria híbrida, defendida por Carnelutti, entende que a arbitragem é contratual em sua fonte, mas jurisdicional no objeto. ${ }^{37}$ Nesse sentido, ainda que o poder dos árbitros derive da vontade das partes o que, inclusive, assegura a constitucionalidade do instituto da arbitragem face ao art. $5^{\circ}$ XXXV da Constituição Federal $^{38}$, isto não exclui o poder jurisdicional que é conferido por lei aos árbitros, na medida em que estes têm legitimidade para solucionar os conflitos submetidos à sua apreciação

\footnotetext{
34 ENEI, José VirgílioLopes. Op. cit., p. 142.

35 Ibid. p. 142.

36 LEMES, Selma. Op. cit., p. 60.

37 Ibid. p. 60.

38 ENEI, José VirgílioLopes. Op. cit., p. 143.
} 
mediante decisão proferida com força de sentença judicial, que independe de homologação pelo Poder Judiciário. 


\section{CAPÍTULO 2 - O CONTRATO DE CONCESSÃO PARA EXPLORAÇÃO, DESENVOLVIMENTO E PRODUÇÃO DE PETRÓLEO E GÁS NATURAL}

Após a campanha popular intitulada "O Petróleo é Nosso", eclodida durante a Era Vargas, foi editada a Lei n ${ }^{\circ} 2.004$, de 03 de outubro de 1951, que criou a sociedade de economia mista intitulada PETROBRAS Petróleo Brasileiro S.A. e instituiu o monopólio estatal sobre a indústria do petróleo. Nesse sentido, referida lei atribuía em caráter de exclusividade à PETROBRAS o direito de exercer as atividades de exploração, produção, refino, comercialização, transporte, importação e exportação de petróleo e derivados.

Mais tarde, o monopólio estatal sobre as atividades da indústria petrolífera ganhou força constitucional, com o advento da Constituição de 1969. No mesmo sentido, a redação original da Constituição de 1988 previa ser "vedado à União ceder ou conceder qualquer tipo de participação, em espécie ou em valor, na exploração de jazidas de petróleo ou gás natural”.

Assim, o monopólio durou 44 anos e foi apenas com o advento da Emenda Constitucional n ${ }^{\circ}$, de 09 de novembro de 1995 que a Constituição da República passou a prever a possibilidade de outorga de concessões e autorizações para o exercício das atividades da indústria petrolífera. Nesse sentido, referida emenda alterou a redação do art. $177, \S 1^{\circ}$ que passou a prever a possibilidade de a União Federal contratar com empresas estatais ou privadas a realização das atividades de pesquisa, lavra, refino, importação, exportação e transporte de petróleo e derivados, passando a PETROBRAS a concorrer em pé de igualdade com as demais empresas. Por oportuno, insta ressaltar que a Constituição manteve a propriedade da União sobre as reservas de hidrocarbonetos, sendo permitida somente a 
outorga de concessões e autorizações das atividades relacionadas à exploração, produção e refino de petróleo. ${ }^{39}$

Mais tarde, a fim de regulamentar os artigos da Constituição alterados por meio da Emenda $n^{\circ} .9 / 1995$, foi promulgada a Lei ${ }^{\circ}$ 9.478, de 06 de agosto de 1997 ("Lei do Petróleo"). Essa lei foi responsável pela criação do Conselho Nacional de Política Energética - CNPE, órgão de assessoramento do Presidente da República com a competência de propor políticas nacionais referentes ao setor energético e da Agência Nacional do Petróleo, Gás Natural e Biocombustíveis - ANP (originalmente denominada "Agência Nacional do Petróleo"), agência reguladora responsável pela regulamentação e fiscalização das atividades petrolíferas.

Além disso, a Lei do Petróleo disciplinou a delegação das atividades petrolíferas pela União, estipulando um regime misto para a outorga desses direitos, abrangendo os institutos da concessão e da autorização, dependendo da atividade que se pretende exercer. Nesse sentido, as atividades de exploração e produção de petróleo e gás natural são outorgadas mediante celebração de contrato de concessão com ANP, precedido de licitação. Por outro lado, as atividades de refino, transporte, distribuição, importação e exportação de petróleo, derivados e gás natural são outorgadas por meio de autorização concedida pela ANP.

Insta ressaltar que o modelo de concessão adotado pelo Brasil (para as áreas do pós-sal e as do pré-sal já concedidas) é o intitulado pela doutrina como concessão moderna. Tal concessão, utilizada também por países como Estados Unidos, Reino Unido Austrália, Argentina e Colômbia é caracterizada pela existência de compromissos exploratórios, de uma legislação básica regulando as condições de execução das atividades de Exploração e Produção (E\&P) e a fiscalização da atividade por parte do

\footnotetext{
${ }^{39}$ BARBOSA, Alfredo Ruy. A Natureza Jurídica da Concessão para Exploração de Petróleo e Gás Natural. p. 6-10. In: VALOIS, Paulo. Temas de Direito do Petróleo e do Gás Natural II. Rio de Janeiro: Lúmen Júris, 2005. 1-28, p. 15.
} 
governo. $^{40}$ Insta ressaltar que o regime de concessão inserido no ordenamento jurídico brasileiro por meio da Lei do Petróleo se contrapõe aos modelos contratuais utilizados em outras jurisdições para a atividade petrolífera, tais como as joint ventures, os contratos de serviços, os contratos de prestação de serviços com cláusula de risco, as licenças e os contratos de partilha de produção ${ }^{41}$, sendo que estes últimos serão adotados no Brasil para a exploração e produção das áreas do Pré-sal e demais áreas estratégicas, conforme previsto na Lei n ${ }^{\circ} .12 .304$, de 02 de agosto de 2010 .

Assim, o modelo contratual escolhido pelo Brasil é caracterizado pela concessão das atividades de exploração e produção, sendo a remuneração do concessionário oriunda da titularidade do produto da lavra (petróleo e gás). Nesse sentido, o particular, que assume integralmente o risco do negócio, além de compromissos exploratórios mínimos e do pagamento das participações governamentais, será recompensado com a transferência da titularidade do petróleo e gás do Estado para si. ${ }^{42}$

Assim, a Lei do Petróleo fixou termos, condições e cláusulas essenciais do Contrato de Concessão para Exploração, Desenvolvimento e Produção de Petróleo e Gás Natural a ser assinado entre o concessionário e a ANP. Desse modo, mister se faz a análise do objeto, natureza jurídica e cláusulas essenciais do referido contrato, a fim de se identificar as suas características básicas e, com base nessas, a arbitrabilidade das controvérsias dele advindas.

\section{1 - Objeto}

O tratamento conferido pelo ordenamento jurídico brasileiro a todos os recursos naturais oriundos do subsolo é análogo, sendo atribuídos a esses

\footnotetext{
${ }^{40}$ TOLMASQUIM, Mauricio Tiomno. Marcos Regulatórios da Indústria Mundial do Petróleo. Rio de Janeiro: Synergia: EPE, 2011. p. $28-31$.

41 RIBEIRO, Marilda Rosado de Sá. Direito do Petróleo: as joint ventures na indústria do petróleo. $2^{\mathrm{a}}$ ed. Rio de Janeiro: Renovar, 2003. p. 163.

${ }^{42}$ TOLMASQUIM, Mauricio Tiomno. Op. cit., p. 28 - 31.
} 
os mesmos princípios e regras gerais. Nesse sentido, sendo o petróleo derivado de uma combinação de substâncias compostas por hidrocarbonetos, gerado nas formações rochosas subterrâneas, juridicamente sempre foi tratado como uma substância mineral. ${ }^{43}$ Portanto, os dispositivos legais e constitucionais de Direito Minerário se aplicam também ao Direito do Petróleo, observadas as especificidades da legislação petrolífera.

Por conta disso, o art. 176, que dissocia a propriedade das jazidas em geral da propriedade do solo, atribuindo à União a titularidade das primeiras é plenamente aplicável às jazidas de petróleo, que são, portanto, consideradas bens públicos per se. Assim, são as jazidas "objeto de direito de propriedade (direito real público, em emprego estrito e técnico do vocábulo "propriedade") do sujeito denominado União". ${ }^{4}$

Em complemento ao art. 176 da Constituição, aplica-se também o art. 177 que é a regra constitucional específica na tutela do Direito do Petróleo. Nesse sentido, além de serem as jazidas propriedade da União, o art. 177, I prevê que as atividades de pesquisa e lavra, ou seja, a exploração das referidas jazidas será praticada pela União, titular de monopólio no exercício dessas atividades. Não obstante, como visto acima, o $\S 1^{\circ}$ do art. 177 da Constituição Federal, admite que a exploração dessas atividades seja efetuada por empresas estatais ou privadas, mediante concessão. ${ }^{45}$ Nesse mesmo sentido dispõem os arts. $3^{\circ}$ e $4^{\circ}$ da Lei do Petróleo.

Desse modo, as jazidas, além dos blocos e da plataforma continental, constituem bens da União, sendo, portanto, inalienáveis e impenhoráveis por natureza. Assim, não se pode conceber que o objeto dos Contratos de Concessão para Exploração, Desenvolvimento e Produção de Petróleo e

\footnotetext{
${ }^{43}$ BARBOSA, Alfredo Ruy. Op. cit., p. 13.

${ }^{44}$ ARAGÃO, Alexandre Santos de. O Contrato de Concessão de Exploração de Petróleo e Gás. Rio de Janeiro: Revista de Direito Administrativo. 239, 411-438, Jan-Mar 2005, p. 425.

${ }^{45}$ Ibid. p. 424.
} 
Gás Natural sejam os blocos em si, por serem estes insuscetíveis de transferência ao particular através de mera obrigação contratual.

Logo, a União, em verdade, concede ao particular, mediante prévia licitação, os direitos referentes ao bloco, dentro da área da concessão, estando o particular autorizado a explorar atividade econômica naquele bem público. Com relação ao produto dessa exploração, ou seja, ao petróleo efetivamente extraído da área da concessão, esse sim é de propriedade do concessionário, em analogia ao direito de propriedade sobre os frutos percebidos. $^{46}$

Confira-se, a esse respeito, o item 2.1 da Cláusula Segunda do Contrato de Concessão da Décima Rodada de Licitações promovida pela ANP:

2.1 Este Contrato tem por objeto a execução, pelo Concessionário, das Operações especificadas no ANEXO II - Programa de Trabalho e Investimento, e qualquer outra atividade adicional de Exploração que o Concessionário possa decidir realizar dentro de cada Bloco integrante da Área da Concessão, visando a permitir que Petróleo e Gás Natural sejam produzidos em condições comerciais na Área da Concessão, e no caso de qualquer Descoberta, a Avaliação, o Desenvolvimento e a Produção dos Hidrocarbonetos pertinentes, tudo nos termos aqui definidos.

Da simples leitura da Cláusula contratual é possível extrair que, como não poderia deixar de ser, o objeto do Contrato de Concessão para Exploração de Petróleo se refere à execução de "operações" ou "qualquer outra atividade" realizadas dentro de cada Bloco integrante da Área da Concessão, visando à exploração e produção de petróleo.

Também nesse sentido dispõe o art. 23 da Lei do Petróleo, segundo o qual "as atividades de exploração, desenvolvimento e produção de petróleo e de gás natural serão exercidas mediante contratos de concessão, precedidos de licitação, na forma estabelecida nesta Lei (...)”.

Sobre o tema ALEXANDRE ARAGÃO ensina que:

\footnotetext{
${ }^{46}$ Ibid.
} 
"Quando se concede, ainda que, coloquialmente, se diga estar a "conceder blocos", não se deve interpretar, por óbvio, que se transfere a coisa (bloco ou jazida), porque esta é bem público. O que se está a transferir é o direito de explorar a atividade correspectiva, o direito de lavra e o direito de prospecção, o que só pode ser efetuado mediante contrato celebrado com a Administração Pública." 47

Além disso, o autor explica que o uso coloquial de expressões como "ganhou o bloco x ou y", ou "ficou com a maioria dos blocos" não traduz a realidade jurídica do contrato. A delimitação física da área em que a atividade econômica cuja exploração está sendo concedida poderá ser exercida (bloco ou área da concessão) é necessária para fins práticos, na medida em que seria impraticável, pela natureza da atividade, a outorga de direitos de exploração de jazidas em todo o território nacional. ${ }^{48}$

Desse modo, o Contrato de Concessão para Exploração, Desenvolvimento e Produção de Petróleo e Gás Natural é o contrato mediante o qual a União, através da ANP, outorga ao particular o direito de explorar bem de sua propriedade, bem como de exercer atividade da qual é titular em regime de monopólio, mediante pagamento das chamadas participações governamentais.

\section{2 - Natureza Jurídica}

O tema da natureza jurídica dos contratos de concessão de direitos de exploração e produção de petróleo é bastante controverso na doutrina pátria. Segundo PAULO VALOIS "há quem diga que o referido contrato tem natureza de: concessão de serviços públicos, serviços de utilidade pública, exploração de bem público, acordo de investimento econômico, de exploração de atividade econômica e até de relação regida pelo Direito Internacional."49

\footnotetext{
${ }^{47}$ Ibid.

48 Ibid.

${ }^{49}$ PIRES, Paulo Valois. A evolução do Monopólio Estatal do Petróleo. Rio de Janeiro: Ed. Lumen Juris, 2000. p. 134.
} 
Primeiramente, cumpre ressaltar que não obstante a sua denominação de "contrato de concessão", não se trata aqui da concessão de serviço público.

A definição de serviço público na doutrina é nebulosa. Tradicionalmente, podemos identificar com facilidade um "núcleo pacífico dos serviços públicos", do qual fazem parte os serviços de: água, luz, iluminação pública, coleta de lixo, limpeza de ruas, correio. ${ }^{50}$ Contudo, referido núcleo está longe de ser taxativo.

Não obstante, conforme defende ODETE MEDAUAR ${ }^{51}$, os serviços públicos referem-se à "atividade prestacional, em que o poder público propicia algo necessário à vida coletiva". No mesmo sentido, HELY LOPES MEIRELLES ${ }^{52}$ adota o conceito segundo o qual o serviço público é prestado pela Administração para satisfazer necessidades essenciais ou secundárias da coletividade. Justamente em razão desse caráter essencial, MARÇAL JUSTEN FILHO aduz à existência de um vínculo direto e imediato da atividade de serviço público e a dignidade humana". ${ }^{3}$

Além disso, a definição de concessão de serviços públicos é dada pelo art. $2^{\circ}$ da Lei $\mathrm{n}^{\circ} 8.987$, de 13 de fevereiro de 1995, conhecida como a Lei das Concessões. Segundo este artigo, concessão de serviço público se trata da delegação da prestação do serviço público, precedida de licitação. Desse modo, tem-se que a concessão de serviço público pressupõe a delegação ao particular ou a empresas estatais da prestação de um serviço essencial à vida da coletividade e à dignidade humana.

Contudo, nas concessões petrolíferas sequer existe delegação de prestação de serviço. Como visto no tópico anterior, o contrato de

\footnotetext{
${ }^{50}$ MEDAUAR, Odete. Direito Administrativo Moderno. 14 ${ }^{\mathrm{a}}$ ed. São Paulo: Editora Revista dos Tribunais, 2010. p. 327.

${ }^{51}$ Ibid. p. 326.

52 MEIRELLES, Hely Lopes. Direito Administrativo Brasileiro. 22 ${ }^{\mathrm{a}}$ ed. São Paulo: Editora Malheiros, 1997. p. 297.

53 JUSTEN FILHO, Marçal. Teoria Geral das Concessões de Serviço Público. São Paulo: Editora Dialética, 2003. p. 30.
} 
concessão ora sob análise transfere ao particular o direito de explorar atividade econômica da qual a União é titular em regime de monopólio, sem que dessa exploração dependa diretamente a dignidade da população. Ainda que se possa argumentar que o petróleo, pela sua relevância na matriz energética do país e do mundo é dotado de interesse público, isso não significa dizer que ao exercer as atividades de exploração e produção o concessionário está prestando, de imediato, um serviço essencial à coletividade, vinculado à dignidade da pessoa humana.

Além disso, a concessão de serviços públicos é calcada no equilíbrio econômico-financeiro do contrato, na medida em que os concessionários são remunerados por meio de tarifas cobradas dos usuários. Contudo, na exploração e produção de petróleo não há que se falar em tarifas e, sequer, em usuários, e a remuneração do concessionário se dá através da propriedade sobre o produto da lavra. Em vista disso, nas concessões petrolíferas não têm aplicabilidade as metas de universalização para o acesso ao serviço público impostas ao concessionário na concessão de serviços públicos, na medida em que uma vez titular do petróleo extraído, o concessionário poderá vendê-lo ou armazená-lo conforme as regras do mercado, bastando que, para tanto, não deixe de observar a "programação de produção" aprovada pela ANP. ${ }^{54}$

Desse modo, a concessão na indústria de petróleo não se trata da concessão tradicional de serviço público. Ou melhor, o concessionário não está de qualquer modo prestando um serviço, mas sim, explorando uma atividade econômica, que pode ser considerada de "utilidade pública" e está sujeita à fiscalização e regulação por parte da ANP.

Esse é o entendimento adotado pela melhor doutrina. ${ }^{55}$ A esse respeito JOAQUIM PAIVA MUNIZ defende que "não há, nessa hipótese

\footnotetext{
${ }^{54}$ MENEZELLO, Maria D'Assunção Costa. Comentários à Lei do Petróleo: lei federal $n^{\circ} 9.478$, de 6-8-1997, São Paulo: Atlas, 2000. p. 55.

${ }^{55}$ É digno de nota o entendimento doutrinário defendido por Maria D’Assunção Costa Menezello, no sentido de que a concessão petrolífera se trata de Concessão de Uso de Bem Público. Contudo,
} 
[pesquisa e lavra de hidrocarbonetos], qualquer serviço público, mas sim a exploração de atividade de natureza econômica, cujo monopólio foi conferido à União."56

Além disso, para JOSÉ EMILIO NUNES PINTO não se pode conferir o mesmo tratamento às concessões para exploração e produção de petróleo e às concessões nos setores de energia elétrica e telecomunicações, por serem os últimos, serviços públicos:

“A questão é ainda mais complexa na indústria de petróleo e gás natural. Já afirmamos, e aqui reiteramos, que essas atividades, diferentemente da energia elétrica e das telecomunicações, se caracterizam como atividades econômicas e não como serviço público." ${ }^{57}$

Insta ressaltar que as atividades econômicas em sentido estrito são exploradas pelo Estado em regime de Direito Privado. Nesse sentido, são norteadas pelos princípios da exploração empresarial, livre iniciativa e livre concorrência, em contraposição aos princípios da continuidade, da igualdade e da mutabilidade, aos quais estão sujeitos os serviços públicos. ${ }^{58}$

Entretanto, se, por um lado, o objeto dos Contratos de Concessão para Exploração e Produção de Petróleo e Gás Natural é a exploração de atividade econômica, por outro, esses contratos se referem a atividades e bens objeto de monopólio da União. Nesse cenário inicia-se a acirrada discussão doutrinária a respeito da natureza jurídica pública ou privada desses contratos. ${ }^{59}$

Ainda que o contrato de concessão para exploração e produção de petróleo pressuponha uma relação jurídica de Direito Privado calcada na livre iniciativa, uma vez que, como visto acima, envolve a exploração de atividade econômica, não é possível se valer dessa assertiva para afastar por

entendemos que o objeto da concessão não é a utilização do bem, mas a possibilidade de explorálo economicamente, transformando-se, o concessionário, em proprietário dos frutos dessa exploração.

${ }_{56}$ MUNIZ, Joaquim de Paiva. Op. cit., p. 96.

${ }^{57}$ NUNES PINTO, José Emilio. A Arbitragem nos Contratos da Indústria do Petróleo e Gás Natural. In: Temas de Direito do Petróleo e Gas Natural II. PIRES, Paulo Valois (Org.). Rio de Janeiro: Lumen Juris, 2005. p. 125-126.

58 JUSTEN FILHO, Marçal. Op. cit., p. 30 - 32.

${ }^{59}$ ARAGÃO, Alexandre Santos de. Op. cit., p. 429. 
completo as normas de Direito Público, considerando que se trata de exploração de bem de propriedade da União e de atividade que constitui monopólio da União. Isso sem mencionar o interesse público envolvido, considerando que o petróleo constitui a base da economia produtiva mundial $^{60}$, correspondendo a $38,6 \%$ da matriz energética brasileira ${ }^{61}$. Especialmente diante das descobertas na área do Pré-sal que, segundo estimativas veiculadas pelo governo brasileiro, devem proporcionar ao País uma receita de US\$28 bilhões com exportações até 2020 e consolidar a posição do Brasil entre maiores produtores de petróleo do mundo. ${ }^{62}$

Desse modo, ainda que a natureza jurídica das concessões petrolíferas seja precipuamente de Direito Privado, de tal fato não decorre qualquer impedimento a que a lei ou o próprio contrato estipulem regras de Direito Público a serem obedecidas pelo concessionário como, por exemplo, a obrigação prevista no art. 43, VI da Lei do Petróleo, que determina a reversão dos bens empregados nas atividades de exploração e produção exercidas pelo concessionário. ${ }^{63}$ Em outras palavras, a natureza jurídica notadamente de Direito Privado desse tipo de contrato de concessão não tem o condão de afastar as normas publicistas, que poderão ser estipuladas pela lei e pelo próprio contrato. Nesse sentido, a autonomia da vontade, típica das relações de Direito Privado puro, será mitigada em nome do interesse público envolvido, especialmente em decorrência da existência de cláusulas essenciais que necessariamente devem estar previstas no contrato. ${ }^{64}$

Contudo, é importante frisar que as referidas normas de Direito Público aplicáveis aos contratos de concessão da indústria do petróleo

\footnotetext{
60 Disponível em: $<$ http://www.brasil.gov.br/sobre/economia/energia/petroleo-gas-natural-ederivados $>$. Acesso em: 16 set. 2012.

${ }_{61}$ Disponível em: <https://ben.epe.gov.br/downloads/Resultados_Pre_BEN_2012.pdf>. Acesso em: 16 set. 2012.

${ }^{62}$ Disponível em: < http://www.brasil.gov.br/sobre/economia/energia/pre-sal $>$. Acesso em: 16 set. 2012.

${ }^{63}$ ARAGÃO, Alexandre Santos de. Op. cit., p. 429.

${ }^{64}$ MENEZELLO, Maria D'Assunção Costa. Op. cit., p. 126 - 127.
} 
devem ser dotadas de previsão expressa, seja na lei, seja no contrato, não havendo espaço aqui para a aplicação imediata de prerrogativas da Administração Pública e sujeições do concessionário decorrentes diretamente do interesse público envolvido. ${ }^{65}$

Ante o exposto, conclui-se que a natureza jurídica do Contrato de Concessão Para Exploração e Produção de Petróleo e Gás Natural é, em linhas gerais, de Direito Privado, uma vez que seu objeto consiste na concessão de direitos de exploração de atividade econômica. Contudo, considerando a propriedade da União sobre as jazidas, o monopólio na atividade de pesquisa e lavra e o interesse público envolvido, os concessionários estão sujeitos às regras de Direito Público, a serem impostas legal e/ou contratualmente. Nesse sentido, as relações jurídicas decorrentes desse contrato podem ser caracterizadas como "multifacetadas", justamente por conterem elementos tanto de Direito Privado, quanto de Direito Público. ${ }^{66}$

\section{3 - Cláusulas Essenciais}

Como visto acima, o Contrato de Concessão para Exploração, Desenvolvimento e Produção de Petróleo e Gás Natural é disciplinado pela Lei do Petróleo. Portanto, o art. 43 da referida lei, estabelece as chamadas "cláusulas essenciais" do referido contrato, que deverão constar necessariamente do contrato.

A primeira cláusula essencial introduzida pelo art. 43 é a definição do bloco objeto da concessão (inciso I). Como visto acima, não obstante a lei fazer referência ao bloco como objeto do contrato, na verdade o objeto da concessão é o "feixe de direitos de explorar"

\footnotetext{
65 Ibid.

${ }^{66}$ MUNIZ, Joaquim de Paiva. Op. cit., p. 97.

${ }^{67}$ ARAG ̃̃O, Alexandre Santos de. Op. cit., p. p. 435.
} 
constitui a parcela da bacia sedimentar levada à licitação, já que o bloco em si é bem da União.

Em seguida, o art. 43 enumera como cláusula essencial o prazo de duração da fase de exploração e as condições para sua prorrogação (inciso II), sendo que na prática o prazo para a fase de exploração (fase destinada à realização de pesquisas) é de três a sete anos e o prazo da fase de produção é de, no máximo, 27 (vinte e sete) anos. ${ }^{68}$

Além disso, ainda de acordo com o art. 43 o contrato deve prever o programa de trabalho e o volume do investimento previsto (inciso III), traduzido no Plano de Desenvolvimento, a ser aprovado pela ANP. ${ }^{69}$

O contrato de concessão das atividades petrolíferas deverá, ainda, estipular as participações governamentais devidas pelo concessionário pela exploração do bem e da atividade cujo monopólio é detido pela União (inciso IV), sendo elas: (i) bônus de assinatura; (ii) royalties; (iii) participação especial; e (iv) pagamento pela ocupação ou retenção de área. ${ }^{70}$

A lei estipula, ainda, como cláusula essencial a indicação das garantias a serem prestadas pelo concessionário, inclusive em relação aos investimentos previstos para cada fase (inciso $\mathrm{V}$ ). ${ }^{71}$

Ademais, o art. 43 prevê que o contrato de concessão da atividade petrolífera deve, ainda, conter cláusula que especifique as regras sobre a devolução e desocupação das áreas, inclusive retirada de equipamentos e reversão de bens (inciso VI). A reversão de bens na atividade petrolífera é objeto de discussão na doutrina, sendo entendida por alguns autores como uma importação inadequada da Lei de Concessões de Serviços Públicos ${ }^{72}$, já que, como visto, não se trata de prestação de serviço público, mas exploração de atividade econômica. Contudo, fato é que a reversão de bens

\footnotetext{
${ }^{68}$ MENEZELLO, Maria D'Assunção Costa. Op. cit., p. 128.

${ }^{69} \mathrm{Ibid}$

${ }^{70}$ Ibid.

${ }^{71}$ MENEZELLO, Maria D'Assunção Costa. Op. cit., p. 128.

${ }^{72}$ Ibid.
} 
é uma realidade fática nos contratos de concessão para exploração de petróleo, revelando a face publicista desse instrumento contratual.

Além disso, os incisos VII, VIII e IV do art. 43 da Lei do Petróleo estipulam como cláusulas essenciais aquelas referentes (i) aos procedimentos para acompanhamento e fiscalização da execução do contrato, a serem exercidos pela ANP; (ii) à obrigação do concessionário de fornecer relatórios, dados e informações à $\mathrm{ANP}^{73}$; e (iii) aos procedimentos relacionados com a transferência do contrato, o que significa que apesar do caráter intuito personae e do Direito Público que também norteia esses contratos, a cessão é admitida. ${ }^{74}$

Já o inciso X do art. 43 da Lei do Petróleo prevê como cláusula essencial a que disciplina as regras sobre solução de controvérsias, relacionadas com o contrato e sua execução, inclusive a conciliação e a arbitragem internacional. Desse modo, a conciliação e a arbitragem nos Contratos de Concessão para Exploração, Desenvolvimento e Produção de Petróleo e Gás Natural são, não apenas admitidas pela legislação pátria, mas, ainda, essenciais a esse contrato. Desse modo, a Lei do Petróleo, em razão da grandeza e relevância dos negócios decorrentes da indústria do petróleo $^{75}$, inovou, estipulando a conciliação e a arbitragem como meios legítimos para a solução dos conflitos decorrentes desses contratos de concessão. Entretanto, conforme será amplamente debatido no capítulo seguinte, a adoção da arbitragem nos contratos de concessão da indústria petrolífera, por acarretar na submissão do Poder Público a um meio extrajudicial de solução de controvérsias, deve respeitar determinados limites.

\footnotetext{
${ }^{73}$ Insta ressaltar que em virtude do interesse público envolvido, o art. 22 da Lei do Petróleo prevê que os dados e informações a respeito das bacias sedimentares são considerados como parte integrante do recurso petrolífero nacional, logo, são propriedade da União.

${ }^{74}$ MENEZELLO, Maria D'Assunção Costa. Op. cit., p. 131.

${ }^{75}$ Ibid. p. 100.
} 
Por fim, são também cláusulas essenciais dos contratos de concessão ora sob análise aquelas referentes às causas de rescisão e extinção do contrato, bem como as penalidades aplicáveis pela ANP aos concessionários em caso de descumprimento das obrigações contratuais, numa expressão do poder fiscalizador e sancionador da ANP com relação ao cumprimento do objeto do contrato de concessão. 


\section{CAPÍTULO 3 - A ARBITRAGEM NO CONTRATO DE CONCESSÃO DE EXPLORAÇÃO E PRODUÇÃO DE PETRÓLEO E GÁS NATURAL}

Conforme abordado nos tópicos anteriores, o contrato de concessão das atividades petrolíferas é dotado de natureza jurídica peculiar, na medida em que é regido precipuamente pelo Direito Privado, havendo, contudo, normas de Direito Público cuja observância se faz obrigatória no âmbito das relações jurídicas decorrentes desse contrato.

Desse modo, não obstante a previsão expressa na lei e no contrato de concessão admitindo a adoção da arbitragem para dirimir as controvérsias oriundas desse contrato, faz-se, ainda, necessária a análise da arbitrabilidade subjetiva e objetiva de tais controvérsias. Para tanto, serão analisados os limites referentes à submissão da Administração Pública em geral à arbitragem, já que uma arbitragem nos termos propostos envolveria a União Federal, através da ANP. Além disso, considerando as relações jurídicas multifacetadas oriundas do contrato de concessão, será necessária, ainda a diferenciação e identificação de quais são os aspectos privados do contrato e quais os que se referem ao interesse público primário, a fim de se determinar a arbitrabilidade objetiva.

\section{1 - Arbitragem na Administração Pública em Geral}

Como visto acima, a arbitragem que se preste a dirimir controvérsias oriundas dos contratos de concessão na indústria petrolífera envolveria órgãos da Administração Pública. Portanto, faz-se necessária a análise da possibilidade e dos limites impostos à submissão do Estado à arbitragem, especialmente diante dos princípios da indisponibilidade do interesse público, da legalidade e da publicidade. 


\subsection{1 - Arbitrabilidade subjetiva: o caso espólio de Henrique Lage vs. União Federal}

No julgamento do Agravo de Instrumento $\mathrm{n}^{\mathrm{o}}$. 52.181 em 14 de novembro de 1973, ou seja, muito antes da edição da Lei de Arbitragem, o Supremo Tribunal Federal entendeu pela primeira vez ser admissível a submissão da Administração Pública ao juízo arbitral. Nesse caso considerado o leading case a respeito do tema, os Ministros por unanimidade reconheceram a legalidade do juízo arbitral para definir a quantia devida a título de indenização decorrente incorporação de bens da Organização Lage durante a Segunda Guerra Mundial. As nuances do referido caso, bem como os argumentos utilizados pelos Ministros serão pormenorizados a seguir.

O Decreto-lei $n^{\circ}$. 9.521, de 26 de julho de 1946 estabeleceu a incorporação, em definitivo, de bens e direitos das empresas da Organização Lage, especificamente os navios Piave, Araquara e Itagiba, considerando o estado de guerra em que se encontrava o país. O Decreto pôs fim à controvérsia a respeito da quantia da indenização devida aos proprietários dos bens, instituindo a competência do juízo arbitral para determinar o quantum devido a título de indenização aos herdeiros dos bens incorporados. Além disso, referido diploma legal foi claro ao determinar que da sentença arbitral não caberia recurso, constituindo esta a "decisão final e definitiva, executável independentemente de homologação". 76

Assim, foi devidamente constituído o juízo arbitral que em 21 de janeiro de 1948 proferiu sentença unanime, concluindo pela indenização no valor de CR \$288.460.812,00 devida aos herdeiros pela incorporação de bens da empresa Organizações Lage.

Em vista da sentença, o governo encaminhou projeto de lei ao Congresso para abertura de crédito para o pagamento da indenização.

\footnotetext{
${ }^{76}$ Extraído do relatório do voto do Ministro Relator do AI 52181, Relator(a): Min. BILAC PINTO, TRIBUNAL PLENO, julgado em 14/11/1973, DJ 15-02-1974.
} 
Contudo, o projeto de lei foi arquivado após parecer do Procurador-Geral da Fazenda pugnando pela inconstitucionalidade do juízo arbitral.

Em razão disso, os herdeiros se socorreram ao Poder Judiciário a fim de obter a indenização devida com base na sentença arbitral. O juiz de primeira instância julgou procedente a ação, determinando o pagamento da indenização. Seguindo a mesma linha, o Tribunal de Recursos, sob relatoria do Ministro Godoy Ilha, entendeu pela legalidade do juízo arbitral.

Em face do acórdão do Tribunal de Recursos a União interpôs dois recursos extraordinários, cuja admissibilidade foi negada pelo Tribunal. Contra referida negativa foi interposto o Agravo de Instrumento $\mathrm{n}^{\mathrm{o}}$. 52.181, julgado pelo Supremo Tribunal Federal.

No Supremo Tribunal Federal o processo teve relatoria do Ministro Bilac Pinto que em seu voto entendeu que "no que concerne à inconstitucionalidade e à ilegalidade do Juízo Arbitral instituído pelo Decreto-lei $n^{\circ}$. 9.521, de 26.7.1946, foram cabalmente respondidas pelo douto voto do ilustre Ministro Godoy Ilha(...)". ${ }^{77}$

A esse respeito, confira-se trecho da ementa do acórdão a respeito da legalidade do Juízo Arbitral:

"Juízo Arbitral - Na tradição do nosso direito, o instituto do Juízo Arbitral sempre foi admitido e consagrado, até mesmo nas causas contra a Fazenda. Pensar de modo diferente é restringir a autonomia contratual do Estado, que, como toda pessoa sui juris, pode prevenir o litígio pela via do pacto de compromisso, salvo nas relações em que age como Poder Público, por insuscetíveis de transação." ${ }^{\text {,78 }}$

Assim, o Tribunal de Recursos adotou, basicamente, os seguintes argumentos para reconhecer a legalidade e constitucionalidade do Juízo Arbitral, que, como visto acima, foram integralmente adotados pelo STF:

i. Inexistência de vedação na Constituição de 1937, vigente ao tempo da edição do Decreto $n^{\circ}$. 9.521, seja expressa ou implícita, a que um Juízo Arbitral fosse instituído nos termos do Decreto.

\footnotetext{
${ }^{77}$ Voto do relator, p. 60 AI 52181, Relator(a): Min. BILAC PINTO, TRIBUNAL PLENO, julgado em 14/11/1973, DJ 15-02-1974.

${ }_{78}$ Ibid.
} 
ii. A admissibilidade do Juízo Arbitral no direito brasileiro desde os tempos do Império.

iii. A autonomia contratual de que é dotada a Fazenda Pública, tendo, portanto, capacidade para assumir o compromisso arbitral.

iv. A natureza contratual privada do objeto da controvérsia dirimida pelo Juízo Arbitral no caso concreto, considerando que se tratava do quantum devido a título de indenização. Nesse ponto é interessante notar que o voto do Ministro Godoy Ilha salienta a impossibilidade de serem decididas pela via arbitral as controvérsias nas quais o Estado age como Poder Público.

Assim, já em 1973 o Supremo Tribunal Federal, adotando as razões de voto do Tribunal Federal de Recursos, reconheceu a possibilidade da Administração Pública se submeter à arbitragem. Desse modo, como já mencionado em capítulo anterior do presente trabalho, o leading case exposto acima declara a arbitrabilidade subjetiva de que são dotadas as controvérsias envolvendo a Administração Pública, ao reconhecer expressamente a capacidade civil e autonomia contratual de que é dotada a Fazenda Pública.

Entretanto, a Suprema Corte não deixou de ressaltar determinados limites à referida submissão, notadamente no que se refere à arbitrabilidade objetiva da controvérsia. Nesse sentido, o STF deixou claro que para que sejam arbitráveis, as controvérsias envolvendo a Administração Pública não podem se referir à atuação do Estado enquanto autoridade.

Essa limitação é igualmente adotada amplamente pela doutrina pátria nos dias atuais e guarda relação com a relevante distinção entre o interesse público primário e o interesse público secundário, a ser detalhadamente exposta a seguir.

\subsection{2 - Interesse Público Primário e Interesse Público Secundário}

O individualismo decorrente dos primados do Direito Civil tomou conta por séculos de diversos setores da ciência, dentre os quais o Direito. ${ }^{79}$

\footnotetext{
79 DI PIETRO, Maria Sylvia Zanella. Direito Administrativo. 24ª ed. São Paulo: Editora Atlas, 2011. p. 66.
} 
Assim, o homem era entendido como "o fim único do direito", sendo a ele voltadas as atividades do Estado.

Contudo, ao final do século XIX nascem as primeiras insurreições contra esse individualismo, decorrentes justamente das consequências sociais, políticas e econômicas que dele advieram. Assim, do antigo individualismo exacerbado que marcava as relações entre a Administração e os particulares, o Estado passou a ser caracterizado como Welfare State, preocupando-se em atingir o interesse público através de suas ações ${ }^{80}$, deixando o Direito de ser um mero instrumento de garantia dos direitos do indivíduo, passando a ser concebido como um meio para a consecução da justiça social, do bem comum e do bem-estar coletivo ${ }^{81}$.

Em vista disso, nasce a ideia de que a atuação da Administração Pública deve pautar-se sob o interesse público. Isso significa que a finalidade última dos atos do Administrador deve ser o atendimento ao interesse geral. Desse modo, as atividades administrativas devem se direcionar ao benefício da coletividade sendo, portanto, o grupo social como um todo o destinatário da atividade administrativa e não o indivíduo $^{82}$.

Desse modo, a doutrina administrativista clássica defende como um dos princípios gerais do Direito Administrativo, o Princípio da Supremacia do Interesse Público, segundo o qual os interesses particulares devem sucumbir ao interesse público. Insta ressaltar que a doutrina mais moderna ${ }^{83}$ vem defendendo uma possível superação do referido princípio, na medida em não se poderia adotar uma prevalência a priori do interesse público sobre o interesse privado ${ }^{84}$, especialmente em virtude da complexidade das

\footnotetext{
${ }^{80}$ CARVALHO Filho, José dos Santos. Manual de Direito Administrativo. $24^{\mathrm{a}}$ ed. Rio de Janeiro: Lumen Iuris, 2011. p. 29.

${ }^{81}$ DI PIETRO, Maria Sylvia Zanella. Op. cit., p. 66.

${ }^{82}$ CARVALHO Filho, José dos Santos. Op. cit., p. 29

${ }^{83}$ Dentre os quais podermos destacar Diogo Figueiredo Moreira Neto, Odete Medauar e Humberto Ávila.

${ }^{84}$ ARAGÃO, Alexandre Santos de. Op. cit., p. 82 - 83.
} 
relações jurídicas e da multiplicidade dos interesses, tanto públicos quanto particulares, sendo, portanto, desarrazoada a pretensão de determinar que toda vez em que se chocarem o interesse público deverá prevalecer.

De todo modo, é pacífico o entendimento de que a atuação do Administrador deve perseguir a consecução do interesse público, sob pena de serem os seus atos eivados de desvio de finalidade.

Contudo, o interesse público não deve ser confundido com o interesse do "aparato estatal". O Estado é sujeito de direito, e por conta disso, possui interesses e conveniências próprios, como ocorre com os particulares $^{85}$. Nesse sentido, não se pode definir o interesse público como o interesse do Estado, tendo em vista que este atua tanto como Administrador, como um player comum do mercado, titular de direitos e obrigações e interesses individuais, se igualando, nesse ponto, ao $\operatorname{particular}^{86}$.

Assim é que, em virtude da dissociação entre o interesse do Estado e o interesse público propriamente dito surge na doutrina italiana a diferenciação entre o interesse público primário e o interesse público secundário. O primeiro consiste nas "atividades-fim de realização das necessidades coletivas" ${ }^{87}$, sendo traduzido no interesse do corpo social a ser perseguido pela Administração Pública. Já o interesse público secundário é o interesse do Estado enquanto sujeito de direito, dissociado do - mas nunca contrário ao - interesse público primário.

Entretanto, é importante notar que ainda que a doutrina adote a diferenciação entre o interesse público primário e o interesse público secundário, não se pode conceber que o primeiro vá de encontro com o segundo. Se, como visto acima, a Administração Pública deve atuar para

\footnotetext{
${ }^{85}$ JUSTEN Filho, Marçal. Curso de Direito Administrativo. $6^{\text {a }}$ ed. Belo Horizonte: Editora Fórum, 2010. p. 123.

${ }^{86}$ DE MELLO, Celso Antonio Bandeira. Curso de Direito Administrativo. $28^{\mathrm{a}}$ ed. São Paulo: Malheiros, 2011. p. 65 e 66.

${ }^{87}$ ARAGÃO, Alexandre Santos de. Op. cit., p. 87.
} 
cumprir com o interesse público primário, seria um contrassenso admitir que esta, ao atingir os seus interesses individuais, contrariasse o interesse geral em que deve pautar-se. Nesse sentido, para que haja legitimidade na persecução dos interesses secundários por parte da Administração é imprescindível que estes estejam em conformidade com o interesse público primário. $^{88}$

A título de exemplo CELSO ANTONIO BANDEIRA DE MELO faz referência à tributação desmesurada por parte do Estado. Ainda que tal atitude atendesse ao interesse público secundário, na medida em que enriqueceria o Erário, não estaria, por óbvio, em consonância com o interesse primário, já que oneraria desarrazoadamente a população. ${ }^{89}$ Diante desse exemplo resta claro que, para que sejam dotados de legitimidade, os atos da Administração que visem assegurar os seus interesses secundários devem também observar os interesses primários, sob pena de desvio de finalidade.

Guarda relação com o tema a antiga classificação utilizada pela doutrina quanto aos atos de império e atos de gestão praticados pela Administração Pública. Surgida no direito francês e desenvolvida pelos italianos essa distinção visava "abrandar a teoria da irresponsabilidade do monarca por danos causados a terceiros. Passou-se a admitir a responsabilidade civil quando decorrente de atos de gestão e afastá-la nos prejuízos resultantes de atos de império." ${ }^{90}$

Assim, os atos de império, ou ius imperii, correspondem aos atos praticados pela Administração Pública no uso das prerrogativas ou privilégios enquanto autoridade, que autorizam que esta sobreponha os seus interesses unilateralmente, independente de autorização judicial para tanto.

\footnotetext{
${ }^{88}$ DE MELLO, Celso Antonio Bandeira. Op. cit., p. 197 e notas de rodapé 3 e 4.

89 Ibid.

${ }^{90}$ DI PIETRO, Maria Sylvia Zanella. Op. cit., p. 222.
} 
${ }^{91} \mathrm{Na}$ seara dos contratos administrativos, os atos de império consistem nas cláusulas que viabilizam a sobreposição do interesse da Administração Pública ao interesse do particular. Nesse sentido, é possível citar como exemplo quando o administrador é autorizado a alterar unilateralmente o contrato, para determinar a sua rescisão ou impor penalidades por falta de cumprimento das obrigações contratuais.

Já os atos de gestão são realizados pela Administração Pública nas ocasiões em que esta atua em pé de igualdade com o particular, ocasiões nas quais a relação jurídica é regulada por normas de direito privado. A finalidade do ato de gestão é a administração do patrimônio público e a exploração de atividades econômicas. ${ }^{92}$

Como mencionado acima, a doutrina administrativista mais moderna considera a distinção entre atos de império e atos de gestão como superada, ou, ainda, "antiga e imprecisa". 93 MARIA SYLVIA ZANELLA DI PIETRO $^{94}$ E CELSO ANTONIO BANDEIRA DE MELLO ${ }^{95}$ defendem que tal distinção fora substituída por outra: atos administrativos de direito privado adotados pela Administração e atos administrativos regidos pelo direito público, sendo que apenas os últimos seriam atos administrativos propriamente ditos.

Não obstante o movimento doutrinário contrário à adoção da distinção entre os atos de império e atos de gestão é interessante notar que a jurisprudência tem-se utilizado dessa classificação, especialmente para determinar se certas matérias são ou não passíveis de revisão pelo poder judiciário, especialmente através de mandado de segurança. ${ }^{96}$

\footnotetext{
${ }^{91}$ MEIRELLES, Hely Lopes, Direito Administrativo Brasileiro, São Paulo: Malheiros, $22^{\mathrm{a}}$ Ed, 1997, p. 149.

${ }^{92}$ DI PIETRO, Maria Sylvia Zanella. Op. cit., p. 222.

93 MOREIRA NETO, Diogo de Figueiredo. Curso de direito administrativo: parte introdutória, parte geral e parte especial. $15^{\mathrm{a}}$ ed. Rio de Janeiro: Ed. Forense, 2009. p. 165.

${ }^{94}$ DI PIETRO, Maria Sylvia Zanella. Op. cit., p. 222.

${ }^{95}$ DE MELLO, Celso Antonio Bandeira. Op. cit., p. 429.

${ }^{96}$ RO .100/RS, Rel. Ministro ALDIR PASSARINHO JUNIOR, SEGUNDA TURMA, julgado em 04/03/2010, DJe 18/03/2010.
} 
Nesse sentido, o Superior Tribunal de Justiça já considerou como ato de império, por exemplo, a desapropriação ${ }^{97}$, atos de Estado estrangeiro em decorrência de sua soberania e o contrato firmado por sociedade de economia mista mediante prévia licitação ${ }^{98}$.

Ante o exposto, ainda que a doutrina rechace a distinção entre atos de império e atos de gestão, entendemos que por uma questão de praticidade não há mal em que essa classificação seja utilizada. Especialmente considerando que não há grandes diferenças entre ela e a nova classificação proposta pela doutrina, a não ser pela intitulação.

Os atos de império estariam relacionados ao interesse público primário, na medida em são oriundos da faceta do Estado-autoridade, ou seja, derivados da supremacia do Estado frente aos particulares, sempre visando à consecução do interesse primário.

Por outro lado, os atos de gestão são praticados quando o Administrador atua em pé de igualdade com o particular, como titular de direitos e obrigações. Isso significa dizer que a Administração Pública pratica atos de gestão ao perseguir o interesse público secundário que, como mencionado acima, deve se coadunar com o interesse primário.

Nesse mesmo sentido, LAURO GAMA ensina que "pela identidade de propósitos e fundamentos, o conceito de interesse público primário é correlato ao de atos de império, e o de interesse público secundário, ao de atos de gestão 99,

Ante o exposto, em virtude da sua complexidade e abrangência, os atos da Administração Pública podem visar à persecução do interesse público primário ou secundário, dependendo se visam tutelar os interesses

\footnotetext{
${ }^{97}$ AgRg nos EDcl no REsp 1263097/SP, Rel. Ministro HUMBERTO MARTINS, SEGUNDA TURMA, julgado em 15/05/2012, DJe 24/05/2012

${ }^{98}$ RESP 789.749/RS, Rel. Ministro Luiz Fux, PRIMEIRA TURMA, julgado em 17/05/2007, DJ 04/06/2007, p. 310.

${ }^{99}$ SOUZA JR., Lauro Gama. Sinal Verde para a Arbitragem nas Parcerias Público-Privadas (A Construção de um Novo Paradigma para os Contratos entre o Estado e o Investidor Privado), Revista Brasileira de Arbitragem. no 8. out-dez 2005, p. 28.
} 
da sociedade ou seus próprios interesses, dos quais é titular por ser dotada de capacidade jurídica. Além disso, tais atos podem ainda ter natureza pública (atos de império) ou privada (atos de gestão) dependendo se decorrem da supremacia Estatal frente ao particular ou não.

\subsection{3 - Princípio da Indisponibilidade do Interesse Público}

O princípio da indisponibilidade do interesse público é um dos princípios fundamentais do Direito Administrativo. Este princípio parte da ideia de que o administrador não tem a propriedade sobre o interesse público de maneira que possa dele dispor. Nesse sentido, o interesse público é confiado ao Estado e não a seus órgãos ou agentes. Logo, a vontade do agente não conta, devendo as atividades do administrador serem orientadas a um fim, condizente com o interesse geral. ${ }^{100}$ Nesse sentido, JOSÉ CRETELLA JÚNIOR ensina que "o proprietário 'dispõe' e o administrador 'administra'". ${ }^{101}$

Contudo, como visto acima, o interesse público pode ser dividido entre o interesse público primário e o interesse público secundário, sendo o interesse público secundário aquele referente ao interesse particular da Administração Pública enquanto titular de direitos e obrigações, não se referindo, portanto, ao interesse da sociedade. Logo, considerando que a indisponibilidade se baseia no fato de que o administrador ao gerir a coisa pública não é titular dos bens e interesses, mas apenas mero gestor, o princípio não deve ser aplicado quando estivermos diante de interesses próprios da Administração e, portanto, dissociados do interesse público em sentido estrito.

\footnotetext{
${ }^{100}$ CRETELLA Júnior, José. Direito administrativo brasileiro. $2^{\mathrm{a}}$ ed. Rio de Janeiro: Forense, 2000. p. 55.

${ }^{101}$ CRETELLA Júnior, José. Op. cit., p. 55.
} 
Desse modo, a doutrina defende uma relativização ${ }^{102}$ do princípio da indisponibilidade do interesse público, aplicando-o apenas às situações que envolvam o interesse da coletividade. Sob esse prisma é possível entender a indisponibilidade absoluta como a regra geral que deve nortear a atuação do Administrador, considerando que os interesses da coletividade não podem ser livremente negociados, a não ser por meio das vias políticas, com base constitucional. Contudo, deve-se admitir a indisponibilidade relativa como exceção, recaindo sobre os interesses públicos derivados, ou seja, aqueles atinentes às pessoas jurídicas que integram a Administração Pública. ${ }^{103}$

Além disso, como visto no tópico anterior, ainda que rechaçada pela doutrina administrativista mais moderna, a distinção entre os atos de império e atos de gestão praticados pelo Poder Público também se faz útil na verificação da aplicação do princípio da indisponibilidade do interesse público. Considerando que os atos de império estão associados ao interesse público primário e os atos de gestão ao interesse público secundário, a indisponibilidade do interesse público se aplica apenas ao exercício de ato de império por parte da Administração Pública. Portanto, apenas os atos praticados no gozo da sua autoridade perante o administrado estariam sujeitos ao princípio da indisponibilidade.

Considerando que, como visto em capítulo anterior, a arbitrabilidade de um controvérsia é determinada, dentre outras, pela disponibilidade dos direitos envolvidos, é possível concluir que são arbitráveis as causas que não envolvam o interesse público primário e atos de império praticados pela Administração Pública. Ou seja, a arbitrabilidade objetiva de uma controvérsia que envolva a Administração Pública é determinada pelo tipo

\footnotetext{
${ }^{102}$ LEMES, Selma. Op. cit., p. 131.

${ }^{103}$ MOREIRA Neto, Diogo Figueiredo. Mutações do Direito Administrativo, $2^{\mathrm{a}}$ ed. Rio de Janeiro: Renovar, 2001. p. 226. Apud SOUZA JR., Lauro Gama. Sinal Verde para a Arbitragem nas Parcerias Público-Privadas (A Construção de um Novo Paradigma para os Contratos entre o Estado e o Investidor Privado). Revista Brasileira de Arbitragem, no. 8, out-dez 2005, p. 28.
} 
de interesse público envolvido, bem como pelo tipo de ato praticado pelo administrador. $^{104}$

Além disso, se a Administração Pública pode dispor de determinados direitos ao estabelecê-los mediante a celebração de contrato administrativo, ou seja, por meio de simples acordo de vontades, não faz sentido que sejam os mesmos direitos entendidos como "indisponíveis" para que seja vedada a submissão voluntária dos litígios decorrentes do contrato administrativo à arbitragem. $^{105}$

Desse modo, impõe-se desfazer o mito que geralmente circunda a suposta contraposição entre a indisponibilidade do interesse público e a utilização da arbitragem para dirimir controvérsias atinentes à Administração Pública. ${ }^{106}$ Isso porque, em razão da pluralidade de interesses geridos pelo administrador, não se pode generalizar e conferir a todos eles o título de "indisponíveis"; é necessário um exercício de ponderação para se determinar quais desses interesses e direitos são primários e quais são secundários, a fim de averiguar a sua disponibilidade e, portanto, a possibilidade de submetê-los à arbitragem.

Esse entendimento encontra respaldo na jurisprudência pátria. Podemos citar o acórdão de relatoria do Ministro Luiz Fux, então integrante do Superior Tribunal de Justiça, que expõe a questão com precisão:

"Erro, muito comum de relacionar a indisponibilidade de direitos a tudo quanto se puder associar, ainda que ligeiramente, à Administração. Deveras, não é qualquer direito público sindicável na via arbitral, mas somente aqueles cognominados como 'disponíveis, porquanto de natureza contratual ou privada. (...) Ao optar pela arbitragem o contratante público não está transigindo com o interesse público, nem abrindo mão de instrumentos de defesa de interesses públicos. Está, sim, escolhendo uma forma mais expedita, ou um meio mais hábil, para a defesa do interesse público."

(STJ, MS 11.308/DF, $1^{a}$ Seção, julgado em 09.04.2008, Rel. Ministro Luiz Fux, DJe 19.05.2008)

\footnotetext{
${ }^{104}$ MUNIZ, Joaquim de Paiva. Op. cit., p. 94.

105 TÁCITO, Caio. Arbitragem nos litígios administrativos. Revista de Direito Administrativo 210/111-115. Rio de Janeiro: Renovar, out-dez, 1997, p. 109.

${ }^{106}$ WALD, Arnoldo e Serrão, André. Aspectos Constitucionais e Administrativos da arbitragem nas concessões. São Paulo: Revista de Arbitragem e Mediação, ano 5. no. 16. jan-mar 2008. p. 22.
} 
Ante o exposto, considerando que os contratos administrativos em geral e também os contratos de concessão na indústria de petróleo trazem disposições e cláusulas diversas, é preciso identificar quais dessas disposições e cláusulas devem ser revestidas da indisponibilidade característica do interesse público primário.

Nesse sentido, no âmbito dos contratos de concessão é possível traçar a diferenciação entre as cláusulas regulamentares e as cláusulas financeiras. As primeiras são aquelas referentes ao objeto, à forma de execução do contrato, condições etc. São cláusulas estipuladas e que podem ser alteradas unilateralmente pela Administração. Ao revés, as cláusulas financeiras se referem ao caráter contratual da obrigação e garantem o direito do concessionário à manutenção do equilíbrio econômico-financeiro do contrato. Nesse sentido, podemos concluir que as cláusulas regulamentares constituem ato de império e, portanto, não são arbitráveis. Por outro lado, as cláusulas financeiras, que visam à submissão da Administração a uma contraprestação financeira não estão submetidas à indisponibilidade do interesse público e, portanto, são plenamente arbitráveis. ${ }^{107}$ Portanto, as questões atinentes a interesses patrimoniais são disponíveis e, portanto, podem ser objeto de arbitragem. Por outro lado, não se pode conferir ao árbitro a decisão sobre a legitimidade de atos administrativos, ou as cláusulas exorbitantes ${ }^{108}$ dos contratos de concessão, mas apenas sobre as suas consequências patrimoniais. ${ }^{109}$

Sob a premissa exposta acima de que as questões puramente patrimoniais oriundas dos contratos de concessão em geral são arbitráveis é possível entender como passíveis de submissão ao juízo arbitral a manutenção e eficácia das cláusulas econômicas, ou seja, o equilíbrio econômico-financeiro do contrato $^{110}$, bem como a revisão de tarifas e

\footnotetext{
${ }^{107}$ LEMES, Selma. Op. cit., p. 395.

${ }^{108}$ NUNES PINTO, José Emilio. Op. cit., p. 125.

109 Ibid.

${ }^{110}$ WALD, Arnoldo e Serrão, André. Op. cit., p. 22.
} 
eventuais indenizações devidas no término do contrato, inclusive as que se refiram à reversão de bens. ${ }^{111}$

Além disso, por não serem dotadas de interesse público primário, são igualmente arbitráveis as controvérsias que envolvam apenas questões de fato oriundas do contrato de concessão. Nesse contexto, é possível a instauração de arbitragem cujo objeto seja determinar a existência ou não de descumprimento de obrigações contratuais pelas Partes ou, ainda, averiguar se determinado dano foi causado por culpa das partes ou de terceiros. $^{112}$

Por outro lado, as cláusulas que se refiram ao exercício do poder de polícia, do poder impositivo, da disposição do domínio público e do controle da prestação dos serviços concedidos são insuscetíveis de solução extrajudicial, por se inserirem na esfera dos direitos indisponíveis. ${ }^{113}$

Além disso, a adoção da arbitragem não pode ser admitida para dirimir controvérsias oriundas do lançamento e o respectivo pagamento, pelas concessionárias de exploração e produção de petróleo, das participações governamentais previstas no art. 45 da Lei do Petróleo. Contudo, adotando o entendimento exposto acima de que ainda que a cláusula em si não seja arbitrável por envolver o interesse público primário, são passíveis de submissão ao juízo arbitral as consequências patrimoniais da respectiva cláusula, a fórmula de cálculo das participações governamentais, bem como a base sobre a qual devem incidir podem ser objeto de procedimento arbitral. ${ }^{114}$

Ainda no contexto específico dos contratos de concessão para exploração e produção de petróleo, temos como indisponíveis as controvérsias que se refiram ao impedimento contratual à exportação e a

\footnotetext{
${ }^{111}$ LEMES, Selma. Op. cit., p. 395.

112 MUNIZ, Joaquim de Paiva. Op. cit., p. 98.

${ }^{113}$ BRANCHER, Paulo. Soluções de Controvérsias e as Agências Reguladoras. Revista Brasileira de Arbitragem, no. 1, jan-mar 2004. p. 46.

${ }^{114}$ Ibid.
} 
obrigação do concessionário de contribuir com o petróleo e gás produzidos para suprir o mercado doméstico em caso de declaração de emergência nacional. ${ }^{115}$ Por outro lado, ainda que a obrigatoriedade da participação do concessionário bem como o tempo que durará o impedimento descrito acima envolvam o interesse público primário, as controvérsias a respeito do volume mensal a ser destinado para cumprir com tal obrigação são passíveis de solução mediante arbitragem. ${ }^{116}$

Não obstante o esforço da doutrina em tentar delimitar os limites para a adoção da arbitragem pelo Estado em geral, incluída nesse contexto a utilização da arbitragem para solucionar conflitos entre o Poder Concedente e o concessionário nos contratos de concessão da indústria petrolífera, fazse, ainda, necessária a análise minuciosa de cada caso específico ${ }^{117}$, a fim de se averiguar a existência ou inexistência de interesse público primário no caso concreto.

Feita a análise sob a ótica da indisponibilidade do interesse público, cumpre analisar a possibilidade de submissão da Administração Pública à arbitragem em razão do princípio da publicidade.

\subsection{4 - Princípio da Publicidade}

Conforme preconiza o caput do art. 37 da Constituição Federal, a Administração Pública está sujeita ao princípio da publicidade. Como se sabe, o administrador não atua em nome próprio ao gerir a coisa pública e, portanto, seus atos e decisões devem ser dotados de transparência, a fim de viabilizar o controle de tais atos e inibir irregularidades, ${ }^{118}$ sendo este

\footnotetext{
115 Cláusula 11.5 do Contrato de Concessão para Exploração, Desenvolvimento e Produção de Petróleo e Gás Natural da $10^{\text {a }}$ Rodada de Licitações promovida pela ANP.

${ }^{116}$ NUNES PINTO, José Emilio. Op. cit., p. 126.

${ }^{117}$ MUNIZ, Joaquim de Paiva. Op. cit., p. 98.

118 JUSTEN Filho, Marçal. Op. cit., p.34.
} 
princípio aplicável a todos os setores e todos os âmbitos da atividade administrativa. ${ }^{119}$

Por outro lado, a arbitragem, costumeiramente, é dotada de privacidade e sigilo. Enquanto a privacidade diz respeito ao local e à matéria discutida, o sigilo se refere ao conteúdo da sentença arbitral e aos documentos constantes dos autos do procedimento arbitral. ${ }^{120}$

Desse modo, em uma primeira análise, no âmbito da submissão da Administração Pública ao juízo arbitral vislumbramos um choque entre o princípio da publicidade e o sigilo e privacidade de que normalmente são dotados os procedimentos arbitrais.

Entretanto, estamos diante, em verdade, de um falso dilema. Isso porque, o sigilo na arbitragem é uma característica facultativa, ou seja, normalmente os procedimentos arbitrais, por convenção das partes, são dotados de confidencialidade, inexistindo determinação legal nesse sentido. Desse modo, demonstra-se plenamente possível que os litigantes abram mão dessa confidencialidade, atribuindo publicidade aos atos referentes ao procedimento arbitral específico.

Logo, na arbitragem em seja parte o Estado o sigilo absoluto não poderá ser adotado pelas partes, em respeito ao princípio da publicidade. Contudo, ainda que as decisões e os atos essenciais do processo arbitral que envolva o Estado devam ser dotados de transparência, o sigilo e a confidencialidade podem ser mantidos no que se refere aos debates e aos documentos que instruíram o processo arbitral ${ }^{121}$.

\footnotetext{
119 MEDAUAR, Odete. Direito Administrativo Moderno, 14 a ed. São Paulo: Editora Revista dos Tribunais, 2010. p. 327.

${ }^{120}$ LEMES, Selma. Op. cit., p. 403.

${ }^{121}$ CARMONA, Carlos Aberto. Op. cit., p. 57.
} 


\subsection{5 - Princípio da legalidade}

Conforme previsto no art. 37 da Constituição Federal, a Administração Pública está sujeita ao princípio da legalidade. Nesse sentido, enquanto o particular pode fazer tudo aquilo que a lei não proíba, ao administrador só lhe é facultado fazer o que a lei permitir. Assim, através da submissão da Administração à lei, obedecer à Administração passa a ser o mesmo que obedecer à lei, e não à simples vontade da autoridade. ${ }^{122}$ Logo, em homenagem ao princípio da separação dos poderes, a atuação do Poder Executivo fica condicionada à uma autorização prévia conferida pelo Poder Legislativo.

Nesse contexto, muitos autores defendem que a submissão do Estado à arbitragem, enquanto meio extrajudicial de solução de controvérsias, deve ser amparada por autorização legislativa.

Contudo, a fim de evitar o engessamento da atuação da Administração Pública, a aplicação do princípio da legalidade deve observar também os demais princípios que informam as atividades da Administração Pública, tais como a eficiência, economicidade, proporcionalidade e razoabilidade. ${ }^{123}$

Assim, não se pode adotar o princípio da legalidade forma estrita, a fim de se defender a necessidade de norma específica autorizando a adoção da arbitragem pela Administração Pública. Isso porque, a necessidade de autorização legal específica para a submissão do Estado ao procedimento arbitral não atende ao princípio da proporcionalidade, na medida em que é uma exigência desnecessária e desproporcional em sentido estrito. Isso porque existem meios menos gravosos aos princípios constitucionais

\footnotetext{
${ }^{122}$ MEDAUAR, Odete, Direito Administrativo Moderno, 14 Ed., São Paulo: Editora Revista dos Tribunais, 2010, p. 127.

${ }^{123}$ LEMES, Selma. Op. cit., p. 99.
} 
contrapostos capazes de assegurar igual ou superiormente o interesse público envolvido. $^{124}$

Como visto acima, o art. $1^{\circ}$ da Lei de Arbitragem autoriza todas as pessoas capazes de contratar a adotarem a arbitragem como meio de solução extrajudicial de controvérsias. Logo, o único requisito imposto pela lei é a capacidade civil e a autonomia contratual. Sendo a Administração Pública um ente personalizado, plenamente capaz de contratar e de atuar na vida civil, o art. $1^{\circ}$ a abrange, já que não a exclui expressamente. ${ }^{125}$

Sob essa interpretação, impedir que a Administração Pública adote a arbitragem para solucionar conflitos decorrentes dos contratos em que seja parte é, em verdade, uma ilegalidade, uma ofensa ao comando legal previsto no art. $1^{\circ}$ da Lei de Arbitragem. ${ }^{126}$

Portanto, a adoção da Arbitragem pelo Estado respeita o princípio da legalidade na medida em que encontra autorização legal prevista no art. $1^{\circ}$ da Lei de Arbitragem. Além disso, especificamente com relação aos contratos de concessão para exploração e produção de petróleo a autorização legislativa é corroborada pelo art. 43, X da Lei do Petróleo, que estipula como cláusula essencial do contrato de concessão a que versa sobre a adoção da arbitragem para solucionar os conflitos oriundos do contrato. Assim, "a existência de normas legais não-específicas aliada aos princípios constitucionais diretores da conduta administrativa revestem de juridicidade o recurso do Poder Público à arbitragem."

Contudo, a arbitragem em que faça parte a Administração Pública não poderá ser realizada com base na equidade, conforme autoriza o art. $2^{\circ}$, $\S 2^{\circ}$ da Lei de Arbitragem. Isso porque, como visto, a Administração está

\footnotetext{
${ }^{124}$ SOUZA JR., Lauro Gama. p. 23.

${ }^{125}$ LEMES, Selma. Op. cit., p. 99.

${ }^{126}$ Ibid. 99.

${ }^{127}$ SOUZA JR., Lauro Gama. p. 24.
} 
adstrita ao princípio da legalidade e, portanto, está sujeita ao que prescreve a lei. $^{128}$

\section{2 - A Cláusula Compromissória nos Contratos de Concessão para Exploração, Desenvolvimento e Produção de Petróleo e Gás Natural}

Como visto acima, o art. 43, X da Lei do Petróleo estipula como cláusula essencial do contrato de concessão para exploração e produção de petróleo aquela referente aos meios de solução de controvérsias, inclusive a arbitragem.

Desse modo, desde a Rodada Zero, ocorrida em 1998, os contratos de concessão de exploração e produção de petróleo contêm cláusula compromissória. Atualmente, tanto no Contrato de Concessão da $10^{\mathrm{a}}$ Rodada de Licitações - a última realizada pela ANP - quanto na minuta do Contrato de Concessão da $11^{a}$ Rodada de Licitações - prevista para ocorrer em maio de $2013^{129}$-, a Cláusula Trigésima - Primeira prevê a possibilidade das partes submeterem uma disputa ou controvérsia oriunda do contrato à arbitragem, caso entendam não existirem condições para uma solução amigável.

Primeiramente, insta ressaltar que a cláusula compromissória nos contratos de concessão para exploração e produção de petróleo prevê a utilização das regras do Regulamento da Corte de Arbitragem da Câmara de Comércio Internacional (CCI) na arbitragem oriunda de contratos de concessão. Contudo, isso não significa dizer que a referida instituição atuará na coordenação dos trabalhos de administração do procedimento arbitral. Ao revés: a cláusula compromissória prevê adoção da arbitragem

\footnotetext{
${ }^{128}$ ZIMMERMANN, Dennys. Alguns aspectos sobre a arbitragem nos contratos administrativos à luz dos princípios da eficiência e do acesso à justiça : por uma nova concepção do que seja interesse público. Revista de Arbitragem e Mediação, São Paulo: Revista dos Tribunais, v. 3, n. 12, p. 69-93, jan./mar. 2007, p.78.

${ }^{129}$ Disponível em:

$<$ http://www.anp.gov.br/?pg $=61965 \& \mathrm{~m}=\& \mathrm{t} 1=\& \mathrm{t} 2=\& \mathrm{t} 3=\& \mathrm{t} 4=\& \mathrm{ar}=\& \mathrm{ps}=\&$ cachebust $=135015117$ 0684>. Acesso em: 13 out. 2012.
} 
ad hoc para a solução das controvérsias oriundas daquele contrato. Isso significa que as partes ficam responsáveis pelo provimento das condições necessárias à condução do procedimento arbitral. ${ }^{130}$

Além de determinar as regras aplicáveis, a cláusula compromissória estabelece que o procedimento arbitral terá sede no Rio de Janeiro, com base nas leis substantivas brasileiras e que o tribunal arbitral será composto por três árbitros ${ }^{131}$, um escolhido por cada parte, que designarão o terceiro árbitro, que atuará como presidente do Tribunal. Isso significa dizer que a cláusula compromissória inserida nesses contratos é uma cláusula compromissória "cheia", na medida em que dispõe de forma minuciosa a respeito das regras, forma de condução e instalação e lei aplicável à arbitragem no âmbito do contrato, ao invés de não detalhar o procedimento, o que caracterizaria a indesejada cláusula arbitral "vazia"132, que, por não detalhar o procedimento arbitral pode ensejar impasse entre as partes no momento em que surge o litígio, sendo necessário recorrer ao Poder Judiciário para que seja instituído o tribunal arbitral ${ }^{133}$.

A cláusula arbitral prevê, ainda, que o idioma a ser utilizado será a língua portuguesa, que a sentença arbitral será definitiva e obrigará as partes, bem como a possibilidade de se recorrer ao Judiciário para a adoção de medidas cautelares, preparatórias ou incidentais, ou outras medidas acautelatórias.

É interessante notar que a redação do art. 43, X da Lei do Petróleo faz menção expressa à arbitragem internacional. Contudo, considerando que a cláusula compromissória prevê o Rio de Janeiro como sede da arbitragem, a língua portuguesa como idioma e a lei brasileira como a

\footnotetext{
${ }^{130}$ BUCHEB, José Alberto. A Arbitragem Internacional nos Contratos da Indústria do Petróleo. Rio de Janeiro: Lumen Iuris, 2002. p. 25.

${ }^{131}$ Insta ressaltar que a minuta do contrato de concessão da $11^{\text {a }}$ Rodada prevê a possibilidade de escolha de apenas um árbitro nas hipóteses em que os valores envolvidos não sejam de grande vulto

${ }^{132}$ NUNES PINTO, José Emilio. Op. cit., p. 127.

${ }^{133}$ CARMONA, Carlos Aberto. Op. cit., p. 115.
} 
aplicável, apenas o fato de ser aplicável o Regulamento da Corte de Arbitragem da Câmara de Comércio Internacional (CCI) e a possibilidade dos árbitros aceitarem depoimentos em inglês sem necessidade de tradução oficial são os elementos de estraneidade da arbitragem no âmbito do contrato de concessão para exploração e produção de petróleo. Nesse sentido, JOSÉ ALBERTO BUCHEB ${ }^{134}$ defende a possibilidade de as partes, de comum acordo, alterarem qualquer item da cláusula compromissória como, por exemplo, transferir o local da sede da arbitragem para o exterior. $\mathrm{O}$ autor salienta que com relação à ANP não haveria, nessa hipótese, violação à indisponibilidade do interesse público, uma vez que existe autorização legal expressa para adoção da arbitragem internacional.

Insta ainda ressaltar que além da cláusula compromissória, o contrato de concessão da atividade petrolífera prevê a cláusula de foro, tendo sido eleito o foro da Justiça Federal - Seção Judiciária do Rio de Janeiro, Brasil. Por possuírem a mesma finalidade - a de estabelecer a forma de solução de conflitos - a cláusula compromissória e a cláusula de foro são, a princípio, conflitantes e opostas, sendo que a coexistência destas em um mesmo contrato pode levar a invalidação de uma delas. ${ }^{135}$

Contudo, é possível a interpretação de que a cláusula de foro em contrato que seja dotado de cláusula compromissória serve para as hipóteses de constituição do tribunal arbitral quando a cláusula compromissória for "vazia" e para medidas de urgência antecedentes à arbitragem. Ou seja, na cláusula de foro as partes escolhem a comarca em que serão propostas as ações que digam respeito à arbitragem. ${ }^{136}$

Além disso, nada impede que a cláusula compromissória seja limitada pelas partes, ou seja, que institua que determinadas matérias

\footnotetext{
${ }^{134}$ BUCHEB, José Alberto. Op. cit., p. 21.

${ }^{135}$ TIBURCIO, Carmen.; MEDEIROS Suzana. Arbitragem na Indústria do Petróleo no Direito Brasileiro. Rio de Janeiro: Revista de Direito Administrativo, 241, jul-set 2005. p. 65.

${ }^{136}$ CARMONA, Carlos Aberto. Op. cit., p. 115.
} 
oriundas da relação jurídica entre as partes sejam dirimidas por arbitragem e outras pelo Poder Judiciário. ${ }^{137}$

Entretanto, a redação da cláusula de foro estabelece que o foro eleito será o competente para dirimir as questões que não versem sobre direitos patrimoniais disponíveis. Dessa redação extraímos que os litígios oriundos desse contrato poderão ou não ser submetidos à arbitragem. Contudo, a cláusula é vaga, não havendo clara definição das matérias que poderão ser submetidas ao juízo arbitral, o que pode ensejar controvérsias entre o concessionário e o poder concedente. ${ }^{138}$ Nesse sentido, entendemos que a fim de identificar quais as controvérsias oriundas do contrato de concessão para exploração e produção de petróleo que poderão ser submetidas à arbitragem, faz-se necessária, sobretudo, a análise exposta acima acerca da submissão da Administração Pública em geral ao procedimento arbitral, tendo em vista, especialmente, o princípio da indisponibilidade do interesse público.

Logo, ainda que a cláusula compromissória exista nos contratos de concessão da indústria petrolífera e seja, ainda, uma cláusula "cheia", a sua aplicação aos litígios oriundos desses contratos não é automática, em razão da eleição de foro e dos limites impostos à solução extrajudicial de litígios envolvendo o Estado. Assim, será necessária uma análise do caso concreto, a fim de se verificar a arbitrabilidade objetiva da controvérsia.

\section{3 - Vantagens da adoção da arbitragem como meio extrajudicial de solução de conflitos}

Até aqui o presente trabalho se prestou à analisar os limites e requisitos para a utilização da arbitragem na solução de controvérsias oriundas dos Contratos de Concessão para Exploração, Desenvolvimento e Produção de Petróleo e Gás Natural. Contudo, uma pergunta se impõe: por

\footnotetext{
${ }^{137}$ Ibid.

${ }^{138}$ BUCHEB, José Alberto. Op. cit., p. 23.
} 
que se valer do procedimento arbitral para solucionar conflitos? Portanto, o presente tópico pretende demonstrar as vantagens oriundas da utilização da arbitragem em geral e especificamente no âmbito do contrato de concessão da atividade petrolífera.

Primeiramente, como vimos, esses contratos de concessão são celebrados com a ANP, de modo que eventual controvérsia entre Concessionário e Poder Concedente envolveria, por óbvio, o Estado. Portanto, os benefícios decorrentes da adoção da arbitragem devem se demonstrar em consonância com os princípios constitucionais.

Como se sabe, os procedimentos arbitrais são dotados de uma especialização técnica da qual é desprovido o Judiciário. Nesse sentido, os membros do Poder Judiciário são, em regra, generalistas e não especialistas, ao passo que em um procedimento arbitral é possível a escolha de árbitros especialistas, que sejam advogados, engenheiros, economistas etc, dependendo da natureza do conflito. Além disso, via de regra, os árbitros terão maior disponibilidade de tempo para dedicar ao procedimento arbitral do que os juízes. ${ }^{139}$

Além disso, o Poder Judiciário é dotado de morosidade e formalismos que tardam a resolução dos conflitos a ele submetidos. Nesse sentido, se comparados com os processos judiciais, os procedimentos arbitrais são mais céleres. A celeridade, além de ser um benefício por si só, acarreta ainda na diminuição de custos. Logo, ainda que a arbitragem seja notoriamente um processo caro, a relação tempo versus custo é positiva em favor do procedimento arbitral. ${ }^{140}$

Nesse sentido, a arbitragem se mostra em consonância com o princípio da eficiência, previsto no caput do art. 37 da Constituição Federal,

\footnotetext{
${ }^{139}$ TIBURCIO, Carmen.; MEDEIROS Suzana. Op. cit., p. 54.

${ }^{140}$ Ibid.
} 
segundo o qual a Administração deve agir de modo rápido e preciso. ${ }^{141}$ Além disso, considerando o melhor custo-benefício ${ }^{142}$ oferecido pela adoção da via arbitral, esta também está de acordo com o princípio da economicidade, segundo o qual os resultados esperados devem ser atingidos com o menor custo possível.

Além disso, a celeridade do processo arbitral atende ao princípio da razoável duração do processo, além de assegurar o acesso à justiça, muitas vezes obstruído pela morosidade e formalismo do Poder Judiciário. ${ }^{143}$

Especificamente com relação aos contratos de concessão para exploração e produção de petróleo é importante salientar que, não obstante a necessidade de constituição de uma empresa subsidiária brasileira para a celebração do contrato de concessão (art. 39, IV da Lei do Petróleo) grande parte das empresas que participam das Rodadas de Licitações promovidas pela ANP são empresas estrangeiras, que se valem de sua capacitação técnica para se habilitar na licitação e, caso se consagrem vencedoras, constituem uma subsidiária com sede no país para assinar o contrato de concessão com a ANP.

Nesse sentido, a cláusula compromissória nos contratos de concessão é um atrativo aos investidores estrangeiros. Isso porque, a possibilidade de haver a apreciação das controvérsias decorrentes do contrato por árbitros neutros, escolhidos pelas partes, em detrimento do Poder Judiciário do país hospedeiro $^{144}$ e a adoção de uma jurisdição segura, célere e tecnicamente especializada, reduz os riscos impostos aos investidores ${ }^{145}$, lhes trazendo maior segurança.

\footnotetext{
${ }^{141}$ MEDAUAR, Odete, Direito Administrativo Moderno, 14 ${ }^{\mathrm{a}}$ Ed., São Paulo: Editora Revista dos Tribunais, 2010, p. 133.

${ }^{142}$ SOUZA JR., Lauro Gama. p. 23.

${ }^{143}$ MORAES, Luiza Rangel de. Arbitragem e Agências Reguladoras. , a. 1, n. 2. mai-ago. São Paulo: Revista de Mediação e Arbitragem, Revista de Arbitragem e Mediação, 2004. p. 73-89.

144 TIBURCIO, Carmen.; MEDEIROS Suzana. 54.

${ }^{145}$ WALD, Arnoldo e Serrão, André. Op. cit., p. 22.
} 
Além disso, pela sua complexidade, a atividade de exploração e produção de petróleo requer altos investimentos, de modo que a celeridade do procedimento arbitral constitui uma vantagem para o Concessionário ${ }^{146}$, especialmente diante da possibilidade de suspensão das atividades objeto do litígio pela ANP até a solução da controvérsia, conforme previsto no item 31.4 do Contrato de Concessão.

Portanto, a utilização da arbitragem para dirimir as controvérsias oriundas dos contratos de concessão da atividade petrolífera se mostra em consonância com os princípios constitucionais aplicáveis, além de atrair investimentos ao setor, ao conferir maior segurança aos investidores, sobretudo, os estrangeiros.

${ }^{146}$ TIBURCIO, Carmen.; MEDEIROS Suzana. 54. 


\section{CONCLUSÃO}

$\mathrm{O}$ instituto da arbitragem vem percorrendo o seu caminho nos ordenamentos jurídicos do mundo inteiro desde o Direito Romano até os dias atuais. No Brasil, foi o advento da Lei de Arbitragem que assegurou a ampla utilização do instituto no país. Contudo, diante do princípio da inafastabilidade de jurisdição previsto no art. $5^{\circ}$, XXXV da Constituição Federal, a Lei de Arbitragem houve por bem instituir os limites para a adoção da arbitragem como meio alternativo de solução de controvérsias. Logo, para que determinado litígio seja solucionado por meio de arbitragem é necessário que seja dotado de arbitrabilidade objetiva, ou seja, que se refira a direitos patrimoniais disponíveis, entendidos como aqueles dotados de valor pecuniário e alienáveis, bem como de arbitabilidade subjetiva, que significa a capacidade das partes de contratar.

Por força dos arts. 176 e 177 da Constituição Federal as jazidas de petróleo são bens da União, que detém o monopólio, dentre outras, da atividade de lavra. Contudo, o parágrafo $1^{\circ}$ do art. 177 da Constituição, introduzido pela Emenda Constitucional $n^{\circ}$ 09/95 que marcou o fim do monopólio da Petrobras sobre as atividades petrolíferas, institui que é facultado à União contratar com empresas estatais ou privadas as atividades relacionadas à exploração e produção de petróleo. Mais adiante com o advento da Lei do Petróleo foi estabelecido que a referida contratação se daria por meio de contrato de concessão, celebrado entre o concessionário e a então recém criada ANP.

Assim, o contrato de Contrato de Concessão para Exploração, Desenvolvimento e Produção de Petróleo e Gás Natural tem como objeto transferir ao concessionário o direito de explorar e produzir petróleo na área da concessão. Contudo, como visto, não obstante ser intitulado de contrato 
de concessão, este não é equivalente às concessões tradicionais, de serviços públicos, haja vista as significativas diferenças entre os institutos. Ao revés, se trata aqui de exploração de atividade econômica pelo concessionário, que arca com todo o risco da atividade e é remunerado mediante titularidade do produto da lavra.

Desse modo, o contrato de concessão das atividades de exploração e produção de petróleo tem natureza jurídica de Direito Privado, já que se trata de exploração de atividade econômica. Contudo, a natureza de Direito Privado não tem o condão de afastar as normas de Direito Público aplicáveis, bem como a fiscalização da ANP, tendo em vista a titularidade da União sobre as jazidas, o monopólio da União sobre a atividade de lavra e o interesse público envolvido. Logo, podemos concluir que se trata de contrato multifacetado, envolvendo aspectos privados e públicos.

Sendo assim, o tema do presente trabalho abrange a questão amplamente discutida na doutrina a respeito da submissão da Administração Pública em geral à arbitragem. Desse modo, analisamos a arbitrabilidade das controvérsias oriundas dos contratos celebrados com a Administração, em especial o contrato de concessão da indústria do petróleo.

A arbitrabilidade subjetiva já foi há muito decidida pelo Supremo no Caso Lage no qual, protegendo a capacidade contratual da Fazenda Publica, os Ministros entenderam pela possibilidade de submissão do Estado ao juízo arbitral, desde que obedecidos os limites referentes à arbitrabilidade objetiva da controvérsia e aos princípios que regem a Administração Pública.

Com relação ao principio da indisponibilidade do interesse público, concluímos que este deve ser relativizado, considerando a pluralidade dos interesses com que lida a Administração Pública. Desse modo, mister se faz a distinção entre o interesse público primário e secundário e os atos de 
império e de gestão. A indisponibilidade recai apenas sobre os atos de império, e o interesse público primário, que ocorrem quando a Administração atua com autoridade, no gozo da sua posição de superioridade em relação ao particular. Logo, concluímos que a arbitragem poderá ser adotada com relação às cláusulas financeiras do contrato celebrado com a Administração Pública, com relação aos aspectos patrimoniais dos atos do Poder Concedente e às questões que versem apenas sobre matéria de fato. Por outro lado, não poderão ser objeto de arbitragem as controvérsias que se refiram ao poder de polícia, à legitimidade de atos administrativos, e ao lançamento e pagamento das participações governamentais.

Já com relação ao princípio da publicidade a nossa conclusão é a de que não obstante ser o sigilo uma característica comumente adotada nos procedimentos arbitrais, não há obrigação legal a que assim seja. Logo, sendo o sigilo uma faculdade, não deve ser exercida nos procedimentos arbitrais em que o Estado seja parte, que deverão ser públicos. Contudo, ainda que as decisões e os atos essenciais do processo arbitral que envolva o Estado devam ser dotados de transparência, o sigilo e a confidencialidade podem ser mantidos no que se refere aos debates e aos documentos que instruíram o processo arbitral.

A respeito do princípio da legalidade verificamos a desnecessidade de autorização legislativa específica para que o Estado se submeta ao juízo arbitral. Isso porque, o art. 1 da Lei de Arbitragem é suficiente, na medida em que coloca como requisito para a adoção da arbitragem apenas a capacidade de contratar. Ora, sendo a Administração Pública, direta e indireta, dotada de plena capacidade, traduzida inclusive na própria celebração do contrato de concessão, está legalmente habilitada a se submeter à arbitragem. Como se isso não bastasse, temos, ainda, como reforço a esse entendimento, o art. 43 da Lei do Petróleo, que prevê como 
cláusula essencial do contrato de concessão aquela que dispõe sobre a arbitragem.

No âmbito específico do contrato de concessão das atividades de exploração e produção de petróleo analisamos a sua cláusula compromissória. Foi possível concluir que se trata de cláusula cheia, ou seja, que prevê o procedimento especifico da arbitragem no âmbito do contrato. Nesse sentido, a arbitragem será regida pelas normas da CCI, terá sede no Rio de Janeiro, com base nas leis brasileiras, e o Tribunal Arbitral será composto por três árbitros, um escolhido por cada parte, que designarão o terceiro, a atuar como Presidente do Tribunal. O idioma será a língua portuguesa, sendo que os árbitros podem admitir documentos e depoimentos em inglês, sem necessidade de tradução oficial.

Por fim, verificamos que da adoção da arbitragem no contrato de concessão da indústria do petróleo advêm muitas vantagens, que atendem ao interesse público ao qual a Administração está vinculada. Assim a arbitragem é dotada de celeridade processual, que assegura o acesso à justiça e a razoável duração do processo. Além disso, a especificação técnica dos árbitros se coaduna com a complexidade da atividade petrolífera, atendendo ao princípio da eficiência. Ademais, o princípio da economicidade também é respeitado em razão do melhor custo benefício do procedimento arbitral em comparação com o processo judicial. Por fim, considerando o grande vulto de investimentos estrangeiros na indústria do petróleo, a cláusula compromissória, por todo o exposto acima, garante maior segurança aos investidores, o que atrai mais investimentos ao setor.

Ante o exposto, observados no caso concreto os limites expostos no presente trabalho, concluímos pela adequação da adoção da arbitragem como meio extrajudicial de solução de controvérsias decorrentes dos contratos de concessão para exploração e produção de petróleo, desde que observados os limites traçados. 


\section{REFERÊNCIAS BIBLIOGRÁFICAS}

ARAGÃO, Alexandre Santos de. Arbitragem e Regulação. Revista de Arbitragem e Mediação, Coord. Arnoldo Wald, ano 7-27, out-dez 2010, Ed. Revista dos Tribunais.

ARAGÃO, Alexandre Santos de. O Contrato de Concessão de Exploração de Petróleo e Gás. Rio de Janeiro: Revista de Direito Administrativo. 239, 411-438, Jan-Mar 2005.

BARBOSA, Alfredo Ruy. A Natureza Jurídica da Concessão para Exploração de Petróleo e Gás Natural. p. 6-10. In: VALOIS, Paulo. Temas de Direito do Petróleo e do Gás Natural II. Rio de Janeiro: Lúmen Júris, 2005. 1-28.

BRANCHER, Paulo. Soluções de Controvérsias e as Agências Reguladoras. Revista Brasileira de Arbitragem, no. 1, jan-mar 2004.

BUCHEB, José Alberto. A Arbitragem Internacional nos Contratos da Indústria do Petróleo. Rio de Janeiro: Lumen Iuris, 2002.

CARMONA, Carlos Aberto. Arbitragem e processo - um comentário à Lei n ${ }^{\circ}$ 9.307/96. $2^{\text {a }}$ ed. São Paulo: Atlas, 2009.

CARREIRA ALVIM, J.E. Comentários à Lei de Arbitragem (Lei $n^{\circ}$ 9.307, de 23/09/1996). 2 ${ }^{\mathrm{a}}$ ed. Atualizada. Rio de Janeiro: Editora Lumen Juris, 2004.

CARVALHO Filho, José dos Santos. Manual de Direito Administrativo. $24^{\mathrm{a}}$ ed. Rio de Janeiro: Lumen Iuris, 2011.

CRETELLA Júnior, José. Direito administrativo brasileiro. $2^{\mathrm{a}}$ ed. Rio de Janeiro: Forense, 2000.

DA SILVA PEREIRA, Cario Mario. Instituiçõs de Direito Civil. 23 a ed. Rio de Janeiro: Forense, 2010.

DE MELLO, Celso Antonio Bandeira. Curso de Direito Administrativo. $28^{\mathrm{a}}$ ed. São Paulo: Malheiros, 2011.

DI PIETRO, Maria Sylvia Zanella. Direito Administrativo. $24^{\mathrm{a}}$ ed. São Paulo: Editora Atlas, 2011.

ENEI, José VirgílioLopes. A arbitragem nas sociedades anônimas. Revista de Direito Mercantil, Industrial, Econômico e Financeiro, São Paulo, n. 129, p. 136-173, jan./mar. 2003. 
GOMES, Orlando. Introdução do direito civil. $10^{\mathrm{a}}$ ed. Rio de Janeiro: Forense, 1988.

http://www.anp.gov.br/?pg=61965\&m=\&t1=\&t2=\&t3=\&t4=\&ar=\&ps=\&ca chebust $=1350151170684$. Acesso em: 13 out. 2012.

http://www.brasil.gov.br/sobre/economia/energia/petroleo-gas-natural-ederivados. Acesso em: 16 set. 2012.

http://www.brasil.gov.br/sobre/economia/energia/pre-sal. Acesso em: 16 set. 2012.

https://ben.epe.gov.br/downloads/Resultados_Pre_BEN_2012.pdf. Acesso em: 16 set. 2012.

JUSTEN Filho, Marçal. Curso de Direito Administrativo. $6^{\mathrm{a}}$ ed. Belo Horizonte: Editora Fórum, 2010.

JUSTEN FILHO, Marçal. Teoria Geral das Concessões de Serviço Público. São Paulo: Editora Dialética, 2003.

LEMES, Selma. Arbitragem na Administração Pública - Fundamentos Jurídicos e Eficiência Econômica. São Paulo: Quartier Latin, 2007.

MARTINS, Pedro A. Batista. Apontamentos sobre a Lei de Arbitragem. $1^{\mathrm{a}}$ ed. Rio de Janeiro: Editora Forense.

MARTINS, Pedro A. Batista. Arbitrabilidade objetiva. Interesse public, indisponibilidade de direitos e normas de ordem pública. no. 50, v. 10, Porto Alegre: Forum, jul-ago 2002.

MATTOS Neto, Antonio José. Direitos Patrimoniais disponíveis e indisponíveis à luz da Lei de Arbitragem, Revista de Processo. São Paulo, v. 27, n. 106, Abril - Jun 2002.

MEDAUAR, Odete, Direito Administrativo Moderno, $14^{\mathrm{a}}$ Ed., São Paulo: Editora Revista dos Tribunais, 2010, p. 127-327.

MEIRELLES, Hely Lopes, Direito Administrativo Brasileiro, São Paulo: Malheiros, 22 ${ }^{\mathrm{a}}$ Ed, 1997, p. 149-297.

MENEZELLO, Maria D'Assunção Costa. Comentários à Lei do Petróleo: lei federal $n^{\circ}$ 9.478, de 6-8-1997, São Paulo: Atlas, 2000.

MORAES, Luiza Rangel de. Arbitragem e Agências Reguladoras. , a. 1, n. 2. mai-ago. São Paulo: Revista de Mediação e Arbitragem, Revista de Arbitragem e Mediação, 2004. p. 73-89. 
MOREIRA NETO, Diogo de Figueiredo. Curso de direito administrativo: parte introdutória, parte geral e parte especial. $15^{\mathrm{a}}$ ed. Rio de Janeiro: Ed. Forense, 2009.

MOREIRA Neto, Diogo Figueiredo. Mutações do Direito Administrativo, $2^{\mathrm{a}}$ ed. Rio de Janeiro: Renovar, 2001. p. 226. Apud SOUZA JR., Lauro Gama. Sinal Verde para a Arbitragem nas Parcerias Público-Privadas (A Construção de um Novo Paradigma para os Contratos entre o Estado e o Investidor Privado). Revista Brasileira de Arbitragem, no. 8, out-dez 2005.

MUNIZ, Joaquim de Paiva, Os Limites da Arbitragem nos Contratos de Concessão de Exploração e Produção de Petróleo e Gás Natural. Revista de Arbitragem e Mediação, ano 1, no. 2, maio - agosto de 2004, p. 90-98.

NUNES PINTO, José Emilio. A Arbitragem nos Contratos da Indústria do Petróleo e Gás Natural. In: Temas de Direito do Petróleo e Gás Natural II. PIRES, Paulo Valois (Org.). Rio de Janeiro: Lumen Juris, 2005. p. 125-127.

PIRES, Paulo Valois. A evolução do Monopólio Estatal do Petróleo. Rio de Janeiro: Ed. Lumen Juris, 2000.

PONTES DE MIRANDA, Comentários, tomo XV, nos. 09 - 10. p. 265266. Apud FIGUEIRA Junior, Joel Dias; Arbitragem, Jurisdição e Execução, São Paulo: Ed. Revista dos Tribunais, 1999.

RESP 789.749/RS, Rel. Ministro Luiz Fux, PRIMEIRA TURMA, julgado em 17/05/2007, DJ 04/06/2007.

RIBEIRO, Marilda Rosado de Sá. Direito do Petróleo: as joint ventures na indústria do petróleo. $2^{\text {a }}$ ed. Rio de Janeiro: Renovar, 2003.

RO .100/RS, Rel. Ministro ALDIR PASSARINHO JUNIOR, SEGUNDA TURMA, julgado em 04/03/2010, DJe 18/03/2010.

ROSSI, Livia. Arbitragem na lei das sociedades anônimas. Revista de Direito Mercantil, Industrial, Econômico e Financeiro, São Paulo, n. 129, p. 186-219, jan./mar.2003.

SOUZA JR., Lauro Gama. Sinal Verde para a Arbitragem nas Parcerias Público-Privadas (A Construção de um Novo Paradigma para os Contratos entre o Estado e o Investidor Privado), Revista Brasileira de Arbitragem. no 8. out-dez 2005.

TÁCITO, Caio. Arbitragem nos litígios administrativos. Revista de Direito Administrativo 210/111-115. Rio de Janeiro: Renovar, out-dez, 1997.

TÁCITO, Caio. O juizo Arbitral em Direito Administrativo. In: Reflexões sobre Arbitragem: in memoriam do Desembargador Cláudio Vianna de 
Lima/coord. Petro A. Batista Martins, José Maria Rossani Garcez - São Paulo: LTr, 2002.

TIBURCIO, Carmen.; MEDEIROS Suzana. Arbitragem na Indústria do Petróleo no Direito Brasileiro. Rio de Janeiro: Revista de Direito Administrativo, 241, jul-set 2005. p. 54-65.

TOLMASQUIM, Mauricio Tiomno. Marcos Regulatórios da Indústria Mundial do Petróleo. Rio de Janeiro: Synergia: EPE, 2011.

Voto do relator, p. 60 AI 52181, Relator(a): Min. BILAC PINTO, TRIBUNAL PLENO, julgado em 14/11/1973, DJ 15-02-1974.

WALD, Arnoldo e Serrão, André. Aspectos Constitucionais e Administrativos da arbitragem nas concessões. São Paulo: Revista de Arbitragem e Mediação, ano 5. no. 16. jan-mar 2008.

ZIMMERMANN, Dennys. Alguns aspectos sobre a arbitragem nos contratos administrativos à luz dos princípios da eficiência e do acesso à justiça : por uma nova concepção do que seja interesse público. Revista de Arbitragem e Mediação, São Paulo: Revista dos Tribunais, v. 3, n. 12, p. 69-93, jan./mar. 2007. 